Revista lus et Praxis, Año 21, No 1, 2015, pp. 217 - 270

ISSN 0717 - 2877

Universidad de Talca - Facultad de Ciencias Jurídicas y Sociales

"La vida privada de los funcionarios públicos frente a dos derechos:

el acceso a la información pública y la libertad de expresión"

Ignacio Covarrubias Cuevas

Trabajo recibido el 23 de mayo y aprobado el 12 de septiembre de 2014

\title{
La vida privada de los funcionarios públicos frente a dos derechos: el acceso a la información pública y la libertad de expresión. (Algunos criterios empleados por la jurisprudencia chilena y comparada y su importancia relativa)*
}

THE PRIVATE LIFE OF PUBLIC OFFICIALS CONFRONTED

WITH THE RIGHT TO ACCESS TO INFORMATION AND THE RIGHT TO EXPRESSION

(SOME OF THE STANDARDS USED BY THE CHILEAN

AND COMPARATIVE DECISIONS AND ITS RELATIVE IMPORTANCE)

Ignacio Covarrubias Cuevas**

\section{RESUMEN}

Este trabajo exhibe los principales criterios de adjudicación empleados por la jurisprudencia nacional y comparada en los casos en que el derecho de acceso a la información y la libertad de expresión han confrontado al derecho a la vida privada de funcionarios públicos. Se sostiene que todos los criterios identificados en dicha relación refieren a uno de ellos -el interés público informativo- como el estándar prevalente respecto del cual los restantes parecen ser accesorios. Se constatará también que varias de las premisas conceptuales bajo las que operan los órganos comparados no son consideradas en nuestro país o bien son aplicadas de manera muy diferente por aquellos órganos que ejercen jurisdicción sobre la materia.

\section{ABSTRACT}

This article exhibits the main adjudication guidelines deployed both by national and comparative judgments in those cases when the rights to access to information and freedom of expression are confronted with the right to informational privacy of public officials. This work claims that all standards identified in such relationship refers to one of them -the public interest in information-as the prevalent one, being the rest secondary in terms of the overall relevance. It will be confirmed, likewise, that several of the conceptual grounds used by comparative agencies and courts are not considered by the same entities in our country or they are applied in a very different fashion.

\footnotetext{
* Este artículo es parte del Proyecto Fondecyt № 11121381, titulado "La intimidad de los funcionarios públicos frente a la Leyes de Prensa y de Acceso a la Información Pública".

** Profesor de Derecho constitucional e investigador del Centro de Justicia Constitucional de la Facultad de Derecho de la Universidad del Desarrollo, Santiago, Chile. Doctor en Derecho (Universidad de los Andes, Chile). Correo electrónico: icovarrubias@udd.

El autor agradece especialmente a su ayudante de investigación Fairus Docmac, por su comprometida colaboración en el presente artículo.
} 
PalABRAs CLAVE

Acceso a la información, Libertad de expresión, Vida privada, Criterios de adjudicación, Relevancia comparativa

\section{KEYWORDS}

Access to information, Freedom of expression, Informational privacy, Standards of judgments, Comparative relevance

\section{Objeto, alcance y perspectiva del trabajo}

Este trabajo pretende, en primer lugar, exhibir los principales lineamientos a partir de los cuales la Constitución y la ley articulan el derecho a la vida privada con la libertad de expresión y el derecho de acceso a la información, del modo en que estos se encuentran regulados por la ley $\mathrm{N}^{\circ} 19.733$ ("Ley de Prensa") y la ley No 20.285 ("Ley de Transparencia", "LT" o "Ley de Acceso"), respectivamente. En segundo término, quiere dar cuenta de los criterios que la jurisprudencia nacional y comparada emplean principalmente cuando el derecho a la intimidad de los funcionarios públicos aparece confrontado con el ejercicio de la libertad de expresión y, asimismo, con el derecho de acceso a la información.

En tercer lugar, verificaremos la importancia relativa de los aludidos criterios -el interés público contenido en la información que se pretende publicar; el modo de resolver la tensión entre los derechos tensionados y la noción de intimidad disminuida de los funcionarios públicos- en los casos reseñados. Constataremos entonces que el criterio real y efectivamente predominante es el interés público, como exigencia sustantiva frente a la que todos los restantes criterios resultan ser accesorios, más allá de lo declarado por los mismos tribunales. En tal contexto, observaremos las coordenadas bajo las cuales se sitúa la jurisprudencia chilena en la materia, entregando algunas opiniones valorativas sobre el tema.

Afirmar que lo crucial es el interés público no es lo novedoso, pues ello ya ha sido sostenido, por diversos autores nacionales y extranjeros, con carácter general o respecto de ciertos aspectos específicos. Lo interesante aquí es observar cómo este estándar se desenvuelve -en una interesante jurisprudencia chilena y comparada de última data- no sólo en la libertad de expresión sino también en el derecho de acceso a la información, en relación a otros dos criterios de adjudicación habitualmente concurrentes en la jurisprudencia y respecto de un asunto más acotado, consistente fundamentalmente en la vida privada de los funcionarios públicos.

No es este un artículo sobre ninguno de los aludidos criterios en particular. Respecto de la noción reducida de la vida privada de las figuras públicas y del test de proporcionalidad en general y en particular, ya hemos dado nuestra 
opinión anteriormente ${ }^{1}$. En relación al interés público, el presente artículo es parte de una línea de trabajo que se encuentra en desarrollo y respecto de la cual esta colaboración constituye un eslabón para futuras publicaciones, como se precisa más adelante.

En cuanto al alcance, no se tratan todos los aspectos de la vida privada de todos los funcionarios públicos. Al abordarse la intimidad de éstos de cara a la Ley de Acceso a la Información Pública y a la Ley de Prensa, hay un sinnúmero de aspectos problemáticos de la vida privada referidas a dichas personas que quedan extramuros de este artículo, por ejemplo, la vida privada del funcionario público frente a su empleador (el Gobierno) o el derecho de acceso frente a los funcionarios del Poder Judicial (Jueces incluidos) y del Congreso Nacional (parlamentarios), por encontrarse éstos fuera del objeto de la Ley de Acceso, aunque ninguno de ellos quedan necesariamente inmunes al eventual alcance de la libertad de expresión.

Otro aspecto metodológico que debe ser advertido es que aquí se asume -como la mayoría de la doctrina y jurisprudencia chilena- que los datos personales constituyen uno de los componentes o manifestaciones protegidas por la esfera del derecho a la vida privada ${ }^{2}$. Finalmente, cabe señalar que no todas las sentencias citadas han podido ser igualmente descritas, ya sea por motivos de espacio, ya sea porque no todas tienen igual relevancia o debido a que algunas de ellas ya han sido expuestas más extensamente por este autor en trabajos anteriores, como se indica más adelante.

\section{Configuración constitucional y legal de ambos derechos en relación con la vida privada}

Más allá de posicionamientos entre posiciones interpretativas, el texto de la Constitución y su contexto son el punto de arranque a partir del cual se guía el sentido y alcance de la Ley Fundamental o de alguna de sus disposiciones, por lo que en esta parte sintetizaremos un panorama sobre el modo en que la Constitución Política ("CPR" o "Constitución") configura la vinculación entre la libertad de información y el derecho de acceso con la vida privada y cómo esta relación es plasmada en las normas legales que desarrollan los dos primeros derechos, a saber, ley No 19.733 ("Ley de Prensa") y ley No 20.285 ("Ley de Transparencia" o "LT").

Por otra parte, y atendido que los convenios internacionales sobre Derechos Humanos tienen, en virtud del artículo $5^{\circ}$ de la CPR, directa aplicación en nues-

1 Covarrubias Cuevas (2012); Covarrubias Cuevas (2013) y Covarrubias Cuevas (2014).

2 Sanz Salguero (2013), pp. 461-462, quien así lo sostiene y cita doctrina al efecto. 
tro país, nos referiremos también al modo en que la Convención Americana de DD.HH. estructura la relación entre la libertad de expresión y la vida privada. Exhibiremos entonces una síntesis de la jurisprudencia de la Corte Interamericana sobre dicha vinculación, donde se advertirá, entre otros aspectos, que para dicho tribunal el derecho de acceso a la información está incorporado en la libertad de expresión.

\subsection{Libertad de información y derecho a la intimidad}

El texto de la CPR no vincula explícitamente la libertad de informar del número 12 del artículo 19 con el derecho a la vida privada reconocido en el número 4 de la misma disposición. En el resto, si bien hay un par de referencias acotadas que autorizan la injerencia estatal en la esfera de bienes protegidos por la intimidad -" interceptar, abrir o registrar (...) toda clase de comunicaciones" en Estado de Sitio ${ }^{3}$ y obligar a ciertos funcionarios públicos a "declarar sus intereses y patrimonio en forma pública" ${ }^{\prime 4}$, en ninguna de ellas se advierte una motivación explícita para limitar el ejercicio de la vida privada en la satisfacción de la libertad de información.

Una primera aproximación contextual sobre la vinculación entre ambos derechos no difiere mucho de lo observado a partir del texto constitucional. Con todo, hay una lectura conforme a la cual es posible constatar una conexión entre la intimidad y libertad de información: concibiendo el principio constitucional de publicidad estatal como manifestación de la libertad de información en su faz de derecho a solicitar y/o a recibir información. Esto, con prescindencia de que la historia de la $\mathrm{LT}^{5}$ y su mismo texto (como veremos enseguida) respalden lo señalado.

Al afirmar la Carta que "[s]on públicos los actos y resoluciones de los órganos del Estado, así como sus fundamentos y los procedimientos que utilicen", parece razonable entender que se ha elevado a rango constitucional no sólo un sano principio de política pública sino también el reconocimiento, aunque sea indirecto, de una manifestación de la libertad de información no explicitada en el

\footnotetext{
${ }^{3}$ Constitución Política de la República, ley № 20.050 de 2005, cuyo artículo 43 dispone: "Por la declaración del estado de asamblea, el Presidente de la República queda facultado para suspender o restringir la libertad personal, el derecho de reunión y la libertad de trabajo. Podrá, también, restringir el ejercicio del derecho de asociación, interceptar, abrir o registrar documentos y toda clase de comunicaciones, disponer requisiciones de bienes y establecer limitaciones al ejercicio del derecho de propiedad".

${ }^{4}$ Constitución Política de la República, ley № 20.414 de 2010, artículo $8^{\circ}$ inciso $3^{\circ}$.

${ }^{5}$ Historia de la ley $N^{\circ} 20.285$, p. 5, donde se señala que "la publicidad de los actos de gobierno, permite que el ciudadano pueda controlar en forma efectiva dichos actos" estatales, con lo cual se reconoce que el referido principio de publicidad estatal comparte con la libertad de expresión la finalidad de contribuir a efectuar un examen del ejercicio del poder gubernamental.
} 
texto del artículo 19 No 12 del texto. Si la CPR prescribe que algo es de público conocimiento se supone que tenemos que tener acceso a ese algo que no puede permanecer en la opacidad. Junto con brindar sustento a partir del cual puede exigirse acceder a aquella información cuyo conocimiento es público, la Constitución también reconoce algunas causales por las cuales se debe denegar el acceso requerido, y una de ellas se funda en que "la publicidad afectare (...) los derechos de las personas" ${ }^{\prime \prime}$, entre los cuales ciertamente está el derecho a la vida privada.

Hasta aquí es evidente la vinculación entre este derecho y la libertad de información en el artículo $8^{\circ}$ de la Carta, comoquiera que una de las fronteras explícitas a la transparencia pública estatal es la información que se encuentra resguardada por la vida privada. Así, aunque la CPR no contempla el derecho a la vida privada como límite explícito de la libertad de informar, sí admite a aquél como una excepción al ejercicio del derecho de acceso a la información pública estatal.

Esto se ve cohonestado cuando la Ley de Prensa señala que el ejercicio de la libertad de informar "incluye (...), buscar y recibir informaciones, y difundirlas por cualquier medio" ${ }^{\prime 7}$, reconoce el derecho de las personas "a ser informadas sobre los hechos de interés general" ${ }^{\prime}$. La referencia a la vida privada aparece aquí en un contexto bastante acotado: al establecer la Ley de Prensa aquellos requisitos que deben concurrir para que la persona acusada de cometer el delito de injuria a través de un Medio de Comunicación Social pueda salvar su responsabilidad penal.

A propósito de la regulación de los delitos de injuria y calumnia cometidos a través de cualquier medio de comunicación social, el artículo 30 de la Ley de Prensa establece que el inculpado de haber causado dichos delitos a través de un medio de comunicación "no le será admitida prueba de verdad acerca de sus expresiones, sino cuando hubiere imputado hechos determinados y concurrieren a lo menos una de las siguientes circunstancias", que luego enumera. Así, la indicada disposición permite al acusado por tales delitos exonerarse de responsabilidad penal, a condición que, en primer término, "se probare la verdad de la imputación", luego, que ésta aludiere a "hechos determinados" y, en tercer lugar, que "se produjere con motivo de defender un interés público real" o, alternativamente, que "el afectado ejerciere funciones públicas y la imputación se refiriere a hechos propios de tal ejercicio" ${ }^{\prime \prime}$.

\footnotetext{
${ }^{6}$ Constitución Política de la República, ley № 20.050, de 2005, artículo $8^{\circ}$ inciso $2^{\circ}$.

${ }^{7}$ Ley $N^{\circ} 19.733$ de 2001, artículo $1^{\circ}$ inciso $1^{\circ}$.

${ }^{8}$ Ley $\mathrm{N}^{\circ} 19.733$ de 2001 , artículo $1^{\circ}$ inciso $3^{\circ}$.

${ }^{9}$ Ley $N^{\circ} 19.733$ de 2001, artículo 30 incisos $1^{\circ}$ y $2^{\circ}$. La disposición legal agrega: "En estos casos, si se probare la verdad de la imputación, el juez procederá a sobreseer definitivamente o absolver al querellado, según correspondiere".
} 
Enseguida, el inciso tercero del artículo 30 afirma que para los efectos de lo preceptuado en esta disposición "se considerarán como hechos de interés público de una persona los siguientes", mencionando allí seis circunstancias, entre las cuales cabe subrayar los hechos "referentes al desempeño de funciones públicas", "Il]os acontecimientos o manifestaciones de que el interesado haya dejado testimonio en registros o archivos públicos, y (...) [I] os consistentes en la comisión de delitos o participación culpable en los mismos", entre otras situaciones que señala a modo meramente ejemplar ${ }^{10}$.

Pues bien, luego de terminar el listado de los hechos estimados como de interés público, el artículo 30 finaliza afirmando que "[s]e considerarán como pertinentes a la esfera privada de las personas los hechos relativos a su vida sexual, conyugal, familiar o doméstica, salvo que ellos fueren constitutivos de delito". De este modo, el legislador, aunque no con la mejor técnica deseable, introduce una excepción a la regla de que los medios de comunicación social, o quienes por su intermedio lo hagan, pueden exonerarse de la responsabilidad en la que habrían incurrido con la comisión de la injuria o cuando la información divulgada versare sobre hechos -que además de ser veraces y determinados- persiguieran satisfacer un "un interés público real" o, bien que "el afectado ejerciere funciones públicas y la imputación se refiriere a hechos propios de tal ejercicio".

Aunque la redacción del inciso final es desafortunada, da a entender que "no se considerarán como hechos de interés público de una persona" aquellos "relativos a su vida sexual, conyugal, familiar o doméstica", por lo que su difusión a través o por un medio de comunicación social no produce, a quien lo profiriese, el efecto liberador de la eventual responsabilidad penal, salvo que la divulgación de tales hechos propios de la vida privada, "fueren constitutivos de delito", introduciendo una contraexcepción a la regla ya indicada.

En fin, en cuanto a los funcionarios públicos, para la Ley de Prensa hay interés público en informar sobre los hechos propios "referentes al desempeño de funciones públicas" que no sean aquellos "relativos a su vida sexual, conyugal, familiar o doméstica", a menos que tales circunstancias fueren constitutivas de delito. Aunque no se dice que tales "hechos" pueden involucrar circunstancias o conductas resguardadas por la vida privada, ello se desprende a contrario sensu de la disposición recién citada, que expresa que no revestirá tal interés la información sensible que indica.

${ }^{10}$ Ley $N^{\circ} 19.733$ de 2001, artículo 30 inciso $3^{\circ}$. Aparte de los indicados, los siguientes hechos que también se consideran de interés público: "b) Los realizados en el ejercicio de una profesión u oficio y cuyo conocimiento tenga interés público real; c) Los que consistieren en actividades a las cuales haya tenido libre acceso el público, a título gratuito u oneroso; d) Las actuaciones que, con el consentimiento del interesado, hubieren sido captadas o difundidas por algún medio de comunicación social (...)". 


\subsection{Derecho de acceso a la información y vida privada}

A diferencia de lo que ocurre entre la libertad de información y la vida privada, en lo que respecta al principio de publicidad de los órganos del Estado, el texto constitucional parece situar a la intimidad fuera de la órbita de alcance de este derecho, en el entendido que éste se estructura fundamentalmente a partir del artículo $8^{\circ}$ de la CPR y de la Ley de Transparencia. La Carta dispuso que una ley especialmente habilitada "podrá establecer la reserva o secreto" de los actos y resoluciones de los órganos del Estado así como de sus fundamentos y procedimientos "cuando la publicidad afectare", entre otras causales, "los derechos de las personas"11. Únicamente en materia de probidad la CPR prescribe que el Presidente de la República, los Ministros de Estado, los diputados y senadores, y las demás autoridades y funcionarios que una ley orgánica constitucional señale "deberán declarar sus intereses y patrimonio en forma pública"12, con lo cual levanta la reserva o secreto de ciertos aspectos protegidos por la intimidad, en su esfera económica y financiera, respecto de determinados servidores públicos. Así, en cuanto al principio de publicidad y probidad, la Carta excluye el derecho a la intimidad de la publicidad, con la expresa salvedad de los intereses y patrimonio de ciertos funcionarios.

Atendido que la Constitución dispuso que las causales de reserva o secreto a la publicidad serían especificadas en una ley de quórum calificado es que se dictó la LT, que contempló explícitamente el "derecho de acceso a la información de los órganos de la Administración del Estado" como asimismo "las excepciones a la publicidad de la información"13. Una de las excepciones previstas fueron las "causales de secreto o reserva en cuya virtud se podrá denegar total o parcialmente el acceso a la información"14. La concerniente a los derechos señala que la denegación tendrá lugar "[c]uando su publicidad, comunicación o conocimiento afecte los derechos de las personas, particularmente tratándose de su seguridad, su salud, la esfera de su vida privada o derechos de carácter comercial o económico"15.

Otras disposiciones de la LT reiteran la exclusión de los derechos de las personas del alcance del acceso a la información. El artículo $5^{\circ}$-norma que aplica tanto a la "Transparencia Activa" como al "derecho de acceso a la información"

\footnotetext{
11 Constitución Política de la República, ley № 20.050 de 2005, artículo $8^{\circ}$ inciso $2^{\circ}$.

${ }^{12}$ Constitución Política de la República, ley № 20.414 de 2010, artículo $8^{\circ}$ inciso $3^{\circ}$.

${ }^{13}$ Ley № 20.285 de 2008, artículo $1^{\circ}$ inciso $1^{\circ}$ : "La presente ley regula el principio de transparencia de la función pública, el derecho de acceso a la información de los órganos de la Administración del Estado (...) y las excepciones a la publicidad de la información".

${ }^{14}$ Ley No 20.285 de 2008, artículo 21.

15 Ley No 20.285 de 2008, artículo 21 № 2.
} 
(Transparencia Pasiva) - afirma que "[e]n virtud del principio de transparencia de la función pública, los actos y resoluciones de los órganos de la Administración del Estado, sus fundamentos, los documentos que les sirvan de sustento o complemento directo y esencial, y los procedimientos que se utilicen para su dictación, son públicos, salvo las excepciones que establece esta ley y las previstas en otras leyes de quórum calificado". En sentido análogo se pronuncia el inciso segundo de la misma disposición legal ${ }^{16}$.

Similar coto vedado a la publicidad prescribe el artículo 10, cuyo inciso primero reconoce a toda persona el "derecho a solicitar y recibir información de cualquier órgano de la Administración del Estado, en la forma y condiciones que establece esta ley". El inciso segundo especifica el ámbito de aplicación del derecho de acceso, haciendo salvedad respecto de "las excepciones legales"17, dentro de las cuales la referida ley prevé "los derechos de las personas" en general y, en particular, la esfera de su vida privada.

En lo referido al estricto ámbito del derecho de acceso, el análisis del contexto de esta ley lleva a la misma conclusión a la que se arriba desde la aislada observación de su texto en cuanto a que-siguiendo el marco de la CPR- la LT situó al derecho a la intimidad extramuros de la órbita de alcance del acceso público, al concebir a los derechos de las personas en general y a la intimidad en especial, como excepciones tanto al principio de publicidad de los órganos del Estado y al derecho de acceso a la información de los actos, resoluciones, fundamentos y procedimientos adoptados por la Administración del Estado.

En el evento que algún dato de la vida privada sea parte de un acto, resolución o del fundamento de éstos, el caso habrá de resolverse prudencialmente de conformidad con el principio de divisibilidad establecido por la LT, "conforme al cual si un acto administrativo contiene información que puede ser conocida e información que debe denegarse en virtud de causa legal, se dará acceso a la primera y no a la segunda"18, considerando además que la LT encomendó al CPLT "[v]elar por la debida reserva de los datos e informaciones que conforme a la Constitución y a la ley tengan carácter secreto o reservado"19.

${ }^{16}$ Ley № 20.285 de 2008, artículo $5^{\circ}$ inciso 2 2: "es pública (...) toda otra información que obre en poder de los órganos de la Administración, cualquiera sea su formato, soporte, fecha de creación, origen, clasificación o procesamiento, a menos que esté sujeta a las excepciones señaladas".

17 Ley No 20.285 de 2008, artículo 10 inciso 20: "El acceso a la información comprende el derecho de acceder a las informaciones contenidas en actos, resoluciones, actas, expedientes, contratos y acuerdos, así como a toda información elaborada con presupuesto público, cualquiera sea el formato o soporte en que se contenga, salvo las excepciones legales".

${ }^{18}$ Ley $N^{\circ} 20.285$ de 2008, artículo 11 letra e).

19 Ley No 20.285 de 2008, artículo 33 letra j). La letra m) añade: "[v]elar por el adecuado cumplimiento de la ley (...) de protección de datos de carácter personal, por parte de los órganos de la Administración del Estado". 


\subsection{La vinculación entre libertad de información e intimidad en la Convención Americana sobre Derechos Humanos y su interpretación por la Corte}

La Convención Americana sobre DD.HH. ("Convención") afirma que el derecho a la libertad de expresión "comprende la libertad de buscar, recibir y difundir informaciones e ideas de toda índole, sin consideración de fronteras, ya sea oralmente, por escrito o en forma impresa o artística, o por cualquier otro procedimiento a su elección". El párrafo segundo añade que el ejercicio de este derecho "no puede estar sujeto a previa censura, sino a responsabilidades ulteriores, las que deben estar expresamente fijadas por la Ley y ser necesaria para asegurar", primeramente, "[E]l respeto a los derechos o a la reputación de los demás" y, luego, "[L]a protección de la seguridad nacional, el orden público o a la salud o la moral pública'20.

Sobre el citado artículo 13, la Corte Interamericana de DD.HH. ("CIDH") ha dicho que al reconocerse expresamente los derechos a "buscar" y a "recibir" "informaciones", la Convención protege el derecho que tiene toda persona a acceder a la información bajo el control del Estado, con las salvedades permitidas bajo el estricto régimen de restricciones establecido en dicho instrumento ${ }^{21}$.

Respecto del alcance del derecho de acceso a la información, la CIDH ha dicho que constituye una herramienta crucial "para evitar abusos de los funcionarios públicos, promover la rendición de cuentas y la transparencia en la gestión estatal, y permitir un debate público sólido e informado que asegure la garantía de recursos efectivos contra los abusos gubernamentales y prevenga la corrupción". Añade que sólo mediante el acceso a la información, bajo control estatal, "que sea de interés público es que los ciudadanos pueden cuestionar, indagar y considerar si se está dando cumplimiento adecuado a las funciones públicas" ${ }^{\prime 22}$.

En relación con las limitaciones al aludido derecho, ha subrayado que el principio de máxima divulgación "establece la presunción de que toda información es accesible, sujeta a un sistema restringido de excepciones ${ }^{\prime 23}$, las cuales

\footnotetext{
${ }^{20}$ Convención Americana sobre Derechos Humanos (Pacto San José de Costa Rica), ratificada por Chile en 1990, artículos 13.1 y 13.2.

${ }^{21}$ Corte Interamericana de Derechos Humanos, Claude Reyes y Otros, Serie C No 151, de 19 de septiembre de 2006, párrafo 76 y 78. En el mismo sentido, los casos Corte Interamericana de Derechos Humanos, López Álvarez vs. Honduras, Serie C № 141, de 1 de febrero de 2006, párrafo 77 y Herrera Ulloa vs Costa Rica, Serie C No 107, de 2 de julio de 2004, párrafo 108.

${ }^{22}$ Corte Interamericana de Derechos Humanos, Claude Reyes y Otros, Serie C No 151, de 19 de septiembre de 2006, párrafo 86-87.

${ }^{23}$ Corte Interamericana de Derechos Humanos, Claude Reyes y Otros, Serie C No 151, de 19 de septiembre de 2006, párrafo 92.
} 
"deben estar previamente fijadas por ley" ${ }^{24}$, responder a un objetivo permitido por la Convención (derechos de terceros, seguridad nacional, el orden público, la salud o la moral públicas) ${ }^{25}$, además de "ser necesarias en una sociedad democrática, lo que depende de que estén orientadas a satisfacer un interés público imperativo" 26 .

Acerca de la exigencia de legalidad de las restricciones, la $\mathrm{CIDH}$ ha precisado que debe tratarse de actos normativos formales adoptados por el órgano legislativo constitucionalmente previsto y democráticamente elegido, según los procedimientos establecidos en la Constitución, por razones de interés general o bien común ${ }^{27}$. Sobre esto último añade que "[e]l requisito según el cual las leyes han de ser dictadas por razones de interés general significa que deben haber sido adoptadas en función del "bien común" (art. 32.2), concepto que ha de interpretarse como elemento integrante del orden público del Estado democrático" 28 .

En cuanto a que las limitaciones deben ser necesarias en una sociedad democrática, la regla general es que para cualquier restricción de derechos, ellas deben estar encaminadas a satisfacer un interés público imperativo y entre varias opciones para alcanzar ese objetivo, "debe escogerse aquélla que restrinja en menor escala el derecho protegido" 29 . Y para el caso de la libertad de expresión se precisa que "la restricción debe ser proporcional al interés que la justifica y debe ser conducente para alcanzar el logro de ese legítimo objetivo, interfiriendo en la menor medida posible en el efectivo ejercicio del derecho" ${ }^{\prime 30}$.

${ }^{24}$ Corte Interamericana de Derechos Humanos, Claude Reyes y Otros, Serie C № 151, de 19 de septiembre de 2006, párrafo 89.

${ }^{25}$ Corte Interamericana de Derechos Humanos, Claude Reyes y Otros, Serie C No 151, de 19 de septiembre de 2006, párrafo 90.

${ }^{26}$ Corte Interamericana de Derechos Humanos, Claude Reyes y Otros, Serie C No 151, de 19 de septiembre de 2006, párrafo 91. Asimismo: Palamara vs Chile, Serie C N ${ }^{\circ} 135$, de 22 de noviembre de 2005, párrafo 85; Ricardo Canese vs Paraguay, Serie C No 111, de 31 de agosto de 2004, párrafo 96; Herrera Ulloa vs Costa Rica, Serie C No 107, de 2 de julio de 2004, párrafo 121-123; y La Colegiación Obligatoria de Periodistas, Opinión Consultiva OC-5/85, Serie A № 5, de 13 de noviembre de 1985, párrafo 46.

${ }^{27}$ Corte Interamericana de Derechos Humanos, Claude Reyes y Otros, Serie C No 151, de 19 de septiembre de 2006, párrafo 89.

${ }^{28}$ Corte Interamericana de Derechos Humanos, Claude Reyes y Otros, Serie C No 151, de 19 de septiembre de 2006, párrafo 89, en que cita La expresión "leyes" en el artículo 30 de la Convención Americana sobre Derechos Humanos, Opinión Consultiva OC-6/86, Serie A N ${ }^{\circ}$ 6, de 9 de mayo de 1986, párrafo 29.

29 NASH (2008), pp. 159-160, y la jurisprudencia allí citada.

${ }^{30}$ Corte Interamericana de Derechos Humanos, Claude Reyes y Otros, Serie C No 151, de 19 de septiembre de 2006, párrafo 91, y asimismo: Corte Interamericana de Derechos Humanos, Herrera Ulloa vs Costa Rica,Serie C No 107, de 2 de julio de 2004, párrafo 85; y La Colegiación Obligatoria 
En términos generales, es posible observar dos rasgos en la formulación entre la libertad de expresión y el derecho a la vida privada. Primero, que los bienes protegidos por el derecho a vida privada -intimidad, datos personales, sensibles, entre otros ${ }^{31}$ - constituyen un límite explícito a la libertad de información y al derecho de acceso, subsumibles bajo la oración "derechos (...) de los demás" a que se refiere el art. 13.2. En segundo lugar, que dicha restricción debe ser legal, perseguir un interés público imperativo, idóneo y de intervención mínima en el ejercicio de la libertad de expresión ${ }^{32}$, con lo cual admite una de las modalidades bajo las que ha operado el test de proporcionalidad ${ }^{33}$. A modo ilustrativo, en Kimel vs. Argentina (2008), la Corte afirmó que la prevalencia de la libertad de expresión o de la honra está determinada por "una adecuada ponderación, la cual deberá hacerse a través de un juicio de proporcionalidad donde la solución al conflicto requerirá el examen de cada caso, conforme a sus características, para apreciar la existencia e intensidad de los elementos en que se sustenta dicho juicio" ${ }^{\prime 34}$.

\section{La vida privada de los funcionarios públicos frente a la libertad de expresión y el derecho de acceso a la información}

\subsection{Vida privada de los funcionarios públicos y derecho de acceso en la jurisprudencia chilena}

Considerando la estricta demarcación trazada por la Carta y la LT entre la vida privada (del funcionario público o de terceros) y el derecho de acceso, el CPLT ha tenido que recurrir básicamente al empleo combinado de dos instrumentos para justificar la incursión, a nombre del ejercicio del derecho de acceso, en la esfera de la vida privada de los funcionarios públicos. El primero afirma que los "funcionarios públicos, poseen una esfera de vida privada más delimitada en virtud precisamente de la función que ejercen" ${ }^{\prime 35}$, noción reiterada

de Periodistas, Opinión Consultiva OC-5/85, Serie A № 5, de 13 de noviembre de 1985, párrafo 46; citado en Corte Interamericana de Derechos Humanos, Palamara vs. Chile, Serie C № 135, de 22 de noviembre de 2005, párrafo 121.

31 García Ricci (2014), pp. 1043-1079. El autor identifica los distintos aspectos de la vida privada reconocidos por la Corte Interamericana.

32 Nogueira Alcalá (2011), pp. 119-156.

33 Covarrubias Cuevas (2014), donde exhibimos que existen varias modalidades del test de proporcionalidad.

${ }^{34}$ García Ricci (2014), p. 1057, en que se refiere a Corte Interamericana de Derechos Humanos, Serie C No 177, de 2 de mayo de 2008, párrafo 51.

${ }_{35}$ Consejo para la Transparencia, rol No A47-09 de 15 de julio de 2009, c. 12 ${ }^{\text {o; }}$ rol $\mathrm{N}^{\circ}$ C816-10 de 7 de enero de 2011, c. $22^{\circ}$ y rol N ${ }^{\circ}$ C626-10 de 18 de enero de 2011, c. $11^{\circ}$; a modo ejemplar. 
en sucesivos pronunciamientos del $\mathrm{CPLT}^{36}$. El segundo consiste en el empleo del test de interés público ("TIP"), por el cual se pretende llevar a cabo un examen entre el beneficio que reportaría revelar la información requerida frente al daño que su divulgación produciría en los derechos. El CPLT dice que el TIP es una aplicación del principio de proporcionalidad ${ }^{37}$.

Ambos argumentos comparten la siguiente premisa: que hay "un bien jurídico superior ${ }^{\prime \prime 38}$-habitualmente identificado con la publicidad de los órganos del Estado- en cuyo beneficio "la privacidad debe ceder"39 a objeto de que la sociedad pueda ejercer un control acerca de cómo se ejercen las funciones públicas. Este bien superior es el "interés público" que, por medio del uso del TIP, justifica la prevalencia del derecho de acceso frente a la vida privada cuando se cumplen los requisitos del mismo test ${ }^{40}$. Empero, en varias ocasiones el CPLT ha otorgado un resguardo (no sujeto a la prevalencia de ningún fin ulterior) cuando datos sensibles ${ }^{41}$ o circunstancias sensibles ${ }^{42}$ de funcionarios (o de terceros) están en juego.

Mientras el argumento de la privacidad reducida se justificaría en la medida que la exhibición de ciertos datos personales del funcionario permite a la sociedad evaluar el desempeño de la función que realiza, el TIP perseguiría evaluar si el beneficio público resultante de conocer la información requerida es mayor que el daño que podría seguirse de su revelación. Así, conocer el Currículum Vitae o la evaluación psico-laboral del funcionario seleccionado

${ }^{36}$ Consejo para la Transparencia, rol No A159-09 de 2 de octubre de 2009, c. $19^{\circ}$; rol No $\mathrm{C} 95-10$ de 29 de junio de 2010, c. $7^{\circ}$; rol $\mathrm{N}^{\circ} \mathrm{C} 713-11$ de 24 de agosto de 2011, c. $2^{\circ}$; rol $\mathrm{N}^{\circ} \mathrm{C} 1033-11$ de 7 de diciembre de 2011, c. $6^{\circ}$; rol $N^{\circ}$ C836-12 de 23 de noviembre de 2012, c. $11^{\circ}$; rol $\mathrm{N}^{\circ} \mathrm{C} 1326-12$ de 5 de diciembre de 2012, c. $11^{\circ}$.

37 Consejo para la Transparencia, rol No A45-09 de 28 de julio de 2009, c. 10 , replicada en rol $\mathrm{N}^{\circ} \mathrm{A} 115-09$ de 22 de septiembre de 2009, c. $9^{\circ}$ y rol $N^{\circ}$ C402-09 de 27 de enero de 2010, c. $13^{\circ}$, a modo ejemplar.

${ }^{38}$ Corte de Apelaciones de Valparaíso, rol № 1560-2012 de 19 de abril de 2013.

${ }^{39}$ Consejo para la Transparencia, rol No A159-09 de 2 de octubre de 2009, c. 19 ${ }^{\circ}$. Asimismo: rol $\mathrm{N}^{\circ}$ C707-12 de 5 de septiembre de 2012, c. $10^{\circ}$; rol $\mathrm{N}^{\circ}$ A307-09 de 8 de enero de 2010, c. $15^{\circ}$.

${ }^{40}$ Consejo para la Transparencia, rol No 115-09 de 22 de septiembre de 20009, c. 90: "cuando la transparencia puede exponer la vida privada (...) existe una barrera que restringe la divulgación de los documentos que contienen esta información. Pese a ello pueden existir circunstancias excepcionales en que el interés público justifique su divulgación".

${ }^{41}$ Consejo para la Transparencia, rol No $\mathrm{C} 198-10$ de 6 de agosto de 2010, c. $8^{\circ}$ y ss., a propósito de los estados de salud físicos o psíquicos de una persona.

${ }^{42}$ Consejo para la Transparencia, rol $\mathrm{N}^{\circ} \mathrm{C} 335-10$ de 20 de agosto de 2010, c. $6^{\circ}$, que replica el criterio de rol $\mathrm{N}^{\circ} \mathrm{A} 53-09$ de 31 de julio de 2009, c. $11^{\circ}$ a $14^{\circ}$, dice que la entrega de los datos -identidad- podría afectar la estabilidad laboral o exponerlos a represalias, por lo que estima necesario no autorizar su difusión, a pesar de no ser sensibles. 
en un concurso público permitiría constatar su idoneidad; saber el resultado de un sumario administrativo nos advertiría del criterio de justicia aplicado en el procedimiento sancionatorio, y acceder a determinados correos electrónicos de un Ministro de Estado nos ilustraría acerca de las motivaciones de ciertas políticas públicas ${ }^{43}$.

La respuesta del Tribunal Constitucional ("TC") y de los Tribunales Superiores de Justicia no se hizo esperar. El argumento de la intimidad devaluada fue desechado por el TC al afirmar la plena titularidad de los funcionarios públicos en sus derechos fundamentales ${ }^{44}$. Dijo que la "Constitución reconoce una amplia titularidad de derechos constitucionales" al asegurar "a todas las personas" los derechos reconocidos en el artículo 19. "En esa amplia titularidad, caben los funcionarios públicos", por lo que "consagra, entonces, que los funcionarios, al igual que el resto de las personas, sean titulares de los derechos fundamentales que ella asegura"45. Añade que dicha titularidad "por parte de funcionarios públicos ha sido reconocida por esta magistratura" en la jurisprudencia que la sentencia cita ${ }^{46}$, además de otra que hemos detectado en fallos que no han sido citados $^{47}$. Con todo, debe admitirse que el sentido categórico de esta afirmación puede ser matizado a la luz de los considerandos de otros fallos del TC, aunque respecto de materias distintas ${ }^{48}$.

Junto con sostener "que los funcionarios públicos tienen derechos constitucionales", agrega que el "régimen estatutario de los funcionarios se limita a regular la actividad funcionarial y no suspende los derechos que la Constitución

\footnotetext{
${ }^{43}$ Un recuento más amplio de algunos casos y su análisis crítico en Covarrubias Cuevas (2012). Asimismo, Covarrubias Cuevas (2013).

${ }_{44}$ Tribunal Constitucional, rol № 2153-2011 de 11 de septiembre de 2012 (Correos Electrónicos l); rol $N^{\circ} 1990-2011$ de 5 de junio de 2012 y rol № 2246-2012 de 31 de enero de 2013. Este es prácticamente idéntico al fallo precedente, por lo que en las citas posteriores nos referiremos al último.

45 Tribunal Constitucional, rol № 2246-2012 de 31 de enero de 2013, c. $18^{\circ}$.

${ }^{46}$ La sentencia se refiere a Tribunal Constitucional, rol № 1990-2011 de 5 de junio de 2012, cuyo c. $42^{\circ}$ dice: "Los funcionarios no son personas de segunda categoría ante la Constitución".

47 Tribunal Constitucional, rol № 226-1995 de 30 de octubre de 1995, c. 25º que dice: "los hombres son titulares de derechos por ser tales".

${ }^{48}$ Tribunal Constitucional, rol No 1463-2009 de 23 de septiembre de 2010, c. 19ª afirma que el derecho a la intimidad "se encuentra especialmente restringido respecto de las personas que ejercen cargos públicos, al igual que respecto de determinados profesionales que se dedican a actividades ante el público" en virtud del "principio democrático, reconocido en el artículo $4^{\circ}$ de la Constitución, que exige que el Gobierno pueda ser objeto de control por parte de la ciudadanía a través del escrutinio público". En un sentido diferente, en rol № 1732-2010 de 21 de junio de 2011, c. $27^{\circ}$, se sostuvo que "se encuentran fuera del ámbito protegido de la vida privada aquellos datos o aspectos que acarrean repercusiones para la ordenación de la vida social y pueden afectar derechos de terceros e intereses legítimos de la comunidad".
} 
garantiza a toda persona"49. De lo contrario, señala, la CPR lo habría establecido de modo expreso, como sucede en aquellas situaciones en que autoriza directamente restricciones al ejercicio de algunos derechos. Da algunos ejemplos ${ }^{50}$ y concluye que la atribución a los funcionarios públicos de la titularidad de los derechos en su condición primigenia de "personas" también "se ve reconocida por el legislador", lo que ilustra con normas legales que establecen "excepcionales restricciones a los derechos constitucionales de los funcionarios públicos", entre ellas, "la declaración de intereses y de patrimonio" de la ley $\mathrm{N}^{\mathrm{o}} 18.575$, en cuya virtud "se afecta la vida privada" ${ }^{51}$ sólo de aquellos que ejercen las funciones que allí se señalan.

Argumentos complementarios en apoyo de la plena titularidad de los funcionarios públicos en su derecho a la vida privada han sido sostenidos también por tribunales superiores. Al fallar reclamaciones en contra de resoluciones del CPLT, la Corte de Santiago ha dicho que ni el artículo $8^{\circ}$ de la CPR ni la referida Ley "consagran un derecho absoluto de acceso a cualquier tipo de información" al establecerse "limitaciones en cuanto a los derechos de las personas, la seguridad de la Nación, el interés nacional y el debido cumplimiento de las funciones de los órganos del Estado" ${ }^{\prime \prime 2}$. Y recientemente la Corte Suprema ha dicho "que el carácter de funcionarios públicos de los titulares de las cuentas en que se alojan los correos de que se trata en nada altera la protección que la Constitución (...) otorga a sus comunicaciones privadas, esto es, que no por tener la calidad de empleados del Estado un determinado grupo de personas ha de ver restringidos sus derechos fundamentales más allá de lo que se resguardan los de la población en general"53.

En cuanto al TIP, en el último de los casos citados, la afirmación del TC es categórica en desechar la procedencia de su aplicación. Lo funda en "que el artículo $8^{\circ}$ de la Constitución no exige ningún test de interés público al momento de analizar la existencia de una causal de secreto o de reserva", por lo que "[s]i se invoca una causal y ésta reúne los requisitos que la Constitución establece, no hay publicidad. No cabe configurar, entonces, un test de propor-

\footnotetext{
49 Tribunal Constitucional, rol No 2246-2012 de 31 de enero de 2013, c. $16^{\circ}$ y $18^{\circ}$ (por ambas citas).

50 Tribunal Constitucional, rol № 2246-2012 de 31 de enero de 2013, c. 18 ${ }^{\circ}$. El ejemplo de "los funcionarios públicos [que] no pueden declararse en huelga" y las Fuerzas Armadas y Carabineros, como cuerpos "esencialmente obedientes y no deliberantes".

51 Tribunal Constitucional, rol № 2246-2012 de 31 de enero de 2013, c. $19^{\circ}$. Entre otros, el fallo ilustra el caso del Estatuto Administrativo, que "obliga a los funcionarios a" (...) "proporcionar, con fidelidad y precisión, los datos que la institución le requiera relativos a situaciones personales o de familia, cuando ello sea de interés para la Administración, debiendo ésta guardar debida reserva de los mismos".

52 Corte de Apelaciones de Santiago, rol No 5077-2012 de 12 de junio de 2013, c. $4^{\circ}$.

53 Corte Suprema, rol № $7484-2013$ de 15 de enero de 2014, c. $12^{\circ}$.
} 
cionalidad cuando la Constitución resolvió, por anticipado, el conflicto". Añade conclusivamente: "No cabe intermediar un test que balancee esta causal con la publicidad. De ahí que, cuando hay un derecho invocado, la reserva vence la publicidad. De lo contrario, los derechos contrapuestos a la publicidad serían excepciones relativas ${ }^{\prime 54}$. La citada afirmación tiene sentido en un contexto en que el TC procura subrayar que si bien la publicidad estatal es importante para el bien común, su promoción debe hacerse respetando los derechos y otros bienes que la CPR aprecia tanto como la publicidad ${ }^{55}$.

Respecto de la jurisprudencia de los Tribunales Superiores, pueden observarse dos criterios en los casos en que se han visto confrontados el acceso a la información con la vida privada de un funcionario o servidor público. El primer criterio, en línea con lo resuelto por el TC, rechaza acudir al TIP (o el test de proporcionalidad) para este tipo de casos, atendido que la vida privada está fuera del derecho de acceso (si no hay colisión, no tiene sentido balancear). El segundo opta por emplear, más bien parcialmente, dicho instrumento de adjudicación, a favor o en contra de la vida privada del funcionario público.

Un ejemplo representativo del primer criterio es aquel en que la Corte Suprema afirma que el Constituyente ha dispuesto la publicidad sólo respecto de aquello que con claridad y precisión dispone el artículo $8^{\circ}$ de la CPR, por lo que concluye que "el acceso a la información, respecto de los órganos del Estado, sólo se refiere o abarca sus actos y resoluciones, así como sus fundamentos y los procedimientos que utilicen, carácter que indudablemente no comparten los correos electrónicos en disputa" ${ }^{\prime 56}$, motivo por el cual desecha la solicitud de acceder al contenido de ciertos correos electrónicos de funcionarios del Servicio de Impuestos Internos. Algunos fallos de la Corte de Apelaciones se han manifestado en el mismo sentido. ${ }^{57}$

El segundo criterio fue pronunciado con ocasión del caso Correos electrónicos que dio lugar a uno de los fallos del TC atrás citados. La Corte Suprema

\footnotetext{
54 Tribunal Constitucional, rol № 2246-2012 de 31 de enero de 2013, c. $67^{\circ}$.

55 Tribunal Constitucional, rol № 2246-2012 de 31 de enero de 2013, c. $26^{\circ}$.

${ }^{56}$ Corte Suprema, rol № 7484-2013 de 15 de enero de 2014, c. $10^{\circ}$.

${ }^{57}$ Corte de Apelaciones de Santiago, rol № 2496-2012 de 23 de julio de 2013, c. 11: "en un ámbito más concreto cabe agregar que los correos electrónicos que se generan en el ámbito de la Administración pueden incluir informaciones de carácter personal, opiniones o juicios de valor respecto de materias confidenciales por razones institucionales o de la naturaleza del cargo, abarcando una multiplicidad de situaciones humanas, por lo que carecen de interés público, más aun cuando los correos no tienen el carácter de documentos que sirvan de sustento a un acto o resolución administrativa pues no constan en algún expediente y por lo tanto no puede catalogarse de información pública. El uso de correos electrónicos reemplaza las llamadas telefónicas o comunicaciones informales que, como se sabe, están también cubiertas por el privilegio deliberativo de las autoridades y funcionarios, no siendo accesibles por la vía de la Ley de Transparencia".
} 
Ilega a la misma conclusión del TC, aunque por la vía del empleo del test. Asume que es el modo de determinar "qué garantía prevalece en pos de la otra con el menor sacrificio posible", dando por sentado la existencia de un conflicto entre el derecho de acceso y el derecho a la vida privada e inviolabilidad de las comunicaciones de quienes forman parte de los órganos estatales. La sentencia dice que tanto la finalidad legítima (la transparencia) como el requisito de adecuación se tienen por cumplidos ${ }^{58}$.

Sin embargo, afirma que no se satisface la exigencia de necesidad, pues "advierte que existen otras vías para conocer lo que el" solicitante buscaba, por lo que "considera prescindible la intervención que se pretende a los correos electrónicos, al existir otras formas no lesivas [menos lesivas] de derechos fundamentales que permiten lograr la finalidad perseguida" ${ }^{59}$. Al no cumplirse este requisito, cree innecesario seguir con la exigencia de proporcionalidad en sentido estricto, aunque agrega "que el acceso a la información pública no es un fin en sí mismo, sino un medio para consolidar la transparencia (...), lo que no se encuentra escarbando en las comunicaciones privadas de sus funcionarios, aun cuando estén contenidas en casillas de correos de quienes ejercen la función pública" ${ }^{\prime \prime 0}$. Por estas consideraciones, fundamentalmente, acoge la causal de reserva o secreto invocada por la autoridad para denegar el derecho de acceso al contenido de ciertos correos electrónicos.

En otras ocasiones, la Corte de Santiago, luego de afirmar que "la publicidad debe sujetarse a la aplicación de lo que la doctrina denomina 'test de daños'", para ponderar "la afectación que la información puede producir", concluye que en tal caso "no se desprende que el hecho de revelar el puntaje asignado a cada atributo del perfil correspondiente a los cargos concursados por la requirente de información, pueda dañar o afectar los bienes jurídicos que se invocan tanto a la peticionaria como a los demás postulantes y a las empresas consultoras, $o$, que afecten el interés nacional", con lo cual se admite que de haberse probado la infracción de tales bienes (confidencialidad de datos, funcionamiento de la Alta Dirección Pública) se habría desvirtuado la presunción legal de que

\footnotetext{
58 Corte Suprema, rol No 5040-2013 de 29 de agosto de 2013, c. 9º que reproduce la sentencia de Corte de Apelaciones de Santiago, rol-2012 de 23 de julio de 2013, que deja a firme. La exigencia de adecuación se entiende cumplida por cuanto se "dio acceso a correos electrónicos, presumiendo que en ellos se puede comprender parte del ejercicio de la función pública" del órgano requerido.

${ }^{59}$ Corte Suprema, rol № 5040-2013 de 29 de agosto de 2013, c. $10^{\circ}$. La vía menos lesiva para "conocer antecedentes respecto al Proyecto de Ley que Perfecciona el Sistema de Alta Dirección Pública" era accediendo a las "actas e informes" del mismo "a través de www.bcn.cl", entre otras alternativas que señala el fallo.

${ }^{60}$ Corte Suprema, rol No 5040-2013 de 29 de agosto de 2013, c. $10^{\circ}$.
} 
la información es de conocimiento público ${ }^{61}$, lo que evidencia que si hubo ponderación no fue con la vida privada ${ }^{62}$.

Existen otros casos análogos al recién señalado en que los tribunales superiores han recurrido o no al empleo de los aludidos test, pero no nos referiremos mayoritariamente a ellos por cuanto no aluden a situaciones en que la confrontación librada tiene lugar entre la vida privada de un funcionario público (o de un candidato a un cargo público) y el derecho de acceso, sino más bien entre el ejercicio de este derecho y la intimidad de un tercero.

\subsection{Vida privada de los funcionarios públicos y acceso a la información en el derecho comparado}

En varios países modelo para Chile en el reconocimiento del derecho de acceso a la información pública, el legislador se antepuso a la hipótesis por la cual del ejercicio de aquel derecho pueden seguirse lesiones a la vida privada de los funcionarios públicos o en aspectos sensibles de dicha esfera. Mientras algunas legislaciones de acceso a la información admitieron la injerencia justificada en la vida privada, otras dejaron a este derecho completamente a salvo de la transparencia gubernamental ${ }^{63}$. Dentro del primer grupo, la Ley de Acceso norteamericana ("FOIA"), impide la entrega de información personal "cuya revelación pública constituiría una clara e injustificada invasión a la privacidad", por lo que la Corte Suprema norteamericana -a partir del texto y recogiendo la historia fidedigna de la $\mathrm{FOIA}^{64}$ - ha dejado abierta la puerta a injerencias en "documentos personales, médicos u otros similares" ${ }^{65}$, justificadas en virtud

\footnotetext{
${ }^{61}$ Corte de Apelaciones de Santiago, rol № 7514-2010 de 26 de julio de 2012, c. $5^{\circ}$ y $6^{\circ}$. Aquí se usó la expresión "test de daños" en vez de "test de interés público", pues aquél se aplica cuando el interés invocado es considerado público ("el debido cumplimiento de las funciones del órgano" en este caso).

${ }^{62}$ Corte de Apelaciones de Santiago, rol № 7514-2010 de 26 de julio de 2012, c. $8^{\circ}$, dice que la información que el CPLT ha ordenado "no afecta derecho alguno por el hecho de acceder a la entrega de puntajes de la propia solicitante y de los demás participantes de los concursos (...) en este último caso, omitiendo el nombre de cada uno de ellos".

${ }^{63}$ Cabe señalar, por ahora, que la legislación mexicana constituye un ejemplo intermedio entre las legislaciones expuestas, pues contiene dos tipos de excepciones: aquellas que no quedan sujetas a ninguna ponderación ulterior y otras que sí admiten -implícitamente- un test de daño, entre las cuales se encuentra la vida privada. Sobre el tema, López AyLLón (2007), pp. 49-65.

64 Informe del Senado, cit. por Halstuk (2000), p. 125: "La frase 'clara e injustificada invasión a la privacidad personal' enuncia la aplicación de una medida que supondrá un balance de intereses entre la protección de los asuntos privados de una persona y la consecución del derecho del público a la información gubernamental".

${ }^{65}$ Covarrubias Cuevas (2012), p. 517: "De las nueve excepciones previstas por la FOIA (...), sólo las referidas a la vida privada -la 6 y 7 -admiten injerencias justificadas en el ámbito de dicho derecho". La 6 protege los "documentos personales, médicos u otros similares cuya revelación pública constituiría
} 
de un proceso "de balanceo entre el derecho del público a saber y el derecho personal a la vida privada" ${ }^{\prime 66}$ protegida por la excepción.

De las ocho ocasiones ${ }^{67}$ en que dicho tribunal ha emitido su opinión sobre la excepción referente a la privacidad personal, sólo en dos casos se ha confrontado la solicitud de acceso con la vida privada de funcionarios públicos. En el primero -Air Force v. Rose (1976) - si bien la Corte reconoció que dar publicidad a sumarios disciplinarios ocurridos en la Fuerza Aérea podría estigmatizar a los afectados, estimó no obstante de alto interés público dar a conocer tales infracciones a la ética y disciplina, ya que la obediencia y confiabilidad son virtudes cruciales para la efectividad militar ${ }^{68}$. En el segundo-Departamento de Defensa v. FLRA (1994)- se desestimó la solicitud de dos sindicatos de un organismo público para que se revelare el domicilio residencial de los funcionarios de dicho organismo. Aunque el máximo tribunal reconoció que había un interés público en la solicitud de acceso, la consecución de dicho interés no traía aparejada la satisfacción de la finalidad de la FOIA de promover el derecho de los ciudadanos a conocer el desempeño de las actividades y operaciones del gobierno, por lo que tal interés era "insignificante" respecto del de los afectados en mantener la reserva de sus domicilios ${ }^{69}$.

Este último sigue el estándar sentado en Air Force v. Rose, caso considerado de capital relevancia (seminal case), pues junto con establecer la naturaleza del interés público apto para confrontar a la vida privada, sirve de precedente en todos los casos venideros en que agencias públicas invocan la excepción número 6 de la FOIA. El criterio sostenido desde entonces por la Corte Suprema norteamericana, luego complementado por Dept. of Justice v. Reporters Committee (1989), afirma que "el único interés público en difundir" digno de ser "ponderado en este balanceo" con la privacidad es el que persigue el "propósito

una clara e injustificada invasión a la privacidad". La 7 (C), protege los documentos sobre investigaciones disciplinarias cuya revelación constituiría una "invasión injustificada de la privacidad personal".

${ }^{66}$ Corte Suprema de los Estados Unidos, U.S. Dept. of Air Force v. Rose 425 U.S. 352, 372 (1976). Asimismo, en NARA v. Favish 541 U.S. 157, 171 (2004), se precisó que "la expresión 'injustificada' nos exige balancear el derecho a la privacidad familiar y el interés público en la transparencia".

67 Hemos detectado ocho casos, desde Air Force v. Rose (1976) hasta el National Archives \& Records Administration v. Favish (2004).

${ }^{68}$ Corte Suprema de los Estados Unidos, U.S Dept. of Air Force v. Rose 425 U.S. 352, 381 (1976).

${ }^{69}$ Corte Suprema de los Estados Unidos, U.S. Dept. of Defense v. Federal Labor Authority 510 U.S. 487, 9-10 (1994): "El interés público relevante en este caso es insignificante". Añade que si bien la revelación de los domicilios contribuye al propósito protegido por la Ley Laboral de facilitar una comunicación más efectiva entre los empleados durante una negociación colectiva, "esto no promovería considerablemente el derecho de los ciudadanos a ser informados de lo que el gobierno hace". 
central de la FOIA' de contribuir significativamente a la pública comprensión de las operaciones o actividades del gobierno" ${ }^{\prime 70}$.

Este criterio -denominado "oficial information test"71 - asume que el "principio de la FOIA de completa apertura, rige a menos que la información esté eximida bajo una regulación legal claramente delineada" y que la "[i]nformación oficial que dé luz acerca del desempeño de los deberes legales de una agencia cae de lleno dentro del propósito"72 de la FOIA. "Dicho propósito" -añade- "no se fomenta con la revelación pública de información, sobre ciudadanos particulares, que se encuentra acumulada en poder del gobierno pero que poco o nada revelan acerca de la conducta del organismo público" ${ }^{\prime 73}$. Conforme a este estándar se ha resuelto la totalidad de los casos posteriores pronunciados en esta materia por la máxima instancia judicial norteamericana ${ }^{74}$.

Es interesante constatar que el único interés público relevante para ponderarse con la vida privada es aquel que persigue la revelación de antecedentes que incidan directamente en la función pública que se desempeña (por lo que no todo interés público vence a la vida privada). En segundo término, se ha observado que incluso en algunos casos en que el interés público está dentro del propósito de la FOIA, éste no alcanza a superar el interés en proteger la confidencialidad $^{75}$. En tercer lugar, ninguna relevancia tiene, en los fallos sobre esta materia, el argumento del tipo intimidad reducida de los funcionarios públicos.

Dentro de las legislaciones bastante restrictivas a la afectación a la vida privada o datos personales por parte del derecho de acceso se encuentra la FOIA británica y la Ley de Acceso a la Información española. La primera excluye el acceso si el requerimiento se refiere a "la Información de carácter personal protegida por la Ley de protección de datos de $1998^{\prime \prime 76}$ y lo hace de un modo

\footnotetext{
${ }^{70}$ Corte Suprema de los Estados Unidos, Dept. of Defense v. Federal Labor Authority 510 U.S. 487, 8 (1994), en que cita Dept. of Justice v. Reporters Committee for Freedom of the Press 489 U.S. 775 (1989).

71 CATE et al. (1994), p. 67, donde define este "test" como un umbral para determinar si la información solicitada bajo la FOIA debería ser revelada públicamente.

72 Corte Suprema de los Estados Unidos, Air Force v. Rose 425 U.S. 352, 360-361 (1976), replicado en Dept. of Justice v. Reporters Committee for Freedom of the Press 489 U.S. 773 (1989) y Bibles v. Oregon 117 U.S. 795 (1997), a modo ejemplar.

${ }^{73}$ Corte Suprema de los Estados Unidos, Dept. of Justice v. Reporters Committee for Freedom of the Press 489 U.S. 773 (1989), en que cita a Air Force v. Rose 425 U.S. 352, 360-361 (1976).

74 Halstuk (2000), p. 135.

${ }^{75}$ En Corte Suprema de los Estados Unidos, U.S. Dept. of State v. Ray (1991) 502 U.S. 164: si bien la Corte dijo que había interés público en saber si el organismo requerido estaba cumpliendo la política prometida (supervigilar la protección de haitianos deportados) el interés en proteger la privacidad y seguridad de éstos era superior.

${ }^{76}$ Freedom of Information Act 2000 chapter 36, de 2000, Section 40.
} 
que basta con que lo solicitado esté comprendido en la categoría singularizada por la excepción para que la autoridad pueda excusarse de proveerla ${ }^{77}$. La absoluta protección de la excepción de "información personal" ha llevado a que el Comisionado de Acceso a la Información Pública ("Comisionado") haya concluido que el acceso al contenido de correos electrónicos de autoridades públicas debiera autorizarse en el estricto entendido de que lo que se está difundiendo no es información privada sino relacionada "con asuntos oficiales de la autoridad pública", esto es, información pública ${ }^{78}$.

Sin perjuicio que la salvedad se encuentre formulada en términos absolutos, tanto si el solicitante pide acceso de datos personales propios ${ }^{79}$ como respecto $^{-}$ de datos personales de terceros, sólo en esta última hipótesis, el Comisionado y el Tribunal de Información Pública ("Tribunal") han interpretado que la revelación de datos personales de un tercero es excepcionalmente procedente ya que la misma FOIA aborda la prohibición en términos que no se "contravenga (i) ninguno de los principios de [la Ley de] protección de datos, o (ii) la sección 10 de dicha Ley (el derecho a impedir que el procesamiento de datos pueda causar eventual perjuicio o aflicción" ${ }^{\prime 80}$. Como los principios de protección de datos personales están expresados como "principios" (antes que una lista prescriptiva de lo que se puede y no se puede)", se ha interpretado que antes que impedir la transparencia, deben permitir el acomodo entre ésta y la protección de la vida privada ${ }^{81}$.

El primero de los ocho principios exige que "los datos personales sean procesados justa y legalmente, debiendo cumplirse al menos (a) una de las exigencias del Apartado 2 y (b) en el caso de información sensible, al menos, una de las exigencias del Apartado 3"82. Entre las condiciones del Apartado 2, están "que el titular de los datos dé su consentimiento" o "que la entrega de datos sea necesaria (...) para la perfección de un contrato del que el titular de los datos es parte" ${ }^{\prime \prime 3}$, entre otros. Lo interesante es que entre las condiciones que

\footnotetext{
77 BROOKE (2005), p. 25, aunque matiza que se trata de una facultad.

78 Information Commisioner's OfFice (2011), p. 2, afirma que lo relevante es el contenido del e-mail, por lo que si contiene información que "se relaciona con asuntos oficiales de la autoridad pública", su ubicación en cuentas privadas no lo exime per se de las normas de la FOIA. En p. 3, reitera que la "Información en cuentas de correo privadas que no dice relación con los asuntos de la autoridad pública no estará sujeta a la FOIA".

${ }^{79}$ La prohibición de entregar a quien solicita acceso respecto de datos personales propios se debe a que debe hacerlo por la vía de la Ley de Datos Personales y no mediante la FOIA.

${ }^{80}$ Freedom of Information Act 2000 chapter 36, de 2000, Section 40 (3) (a) (i) y (ii).

81 TURLE (2007), p. 517.

82 Data Protection Act 1998 chapter 29, de 1998, Section 1 (a) y (b).

83 Data Protection Act 1998 chapter 29, de 1998, Schedule 2, (1), (2) (a), (4).
} 
prevé para que la entrega de datos personales sea justa y legal están los motivos de interés público, esto es, que "que [la entrega] sea necesaria (a) para la administración de justicia, (b) para el ejercicio de las funciones de cualquiera de las Cámaras del Parlamento (...), (c) para el ejercicio de las funciones de la Corona, de un Ministro de la Corona o de un departamento gubernamental, o (d) para el ejercicio de cualquier otra función de naturaleza pública desempeñadas en el interés público por cualquier persona" ${ }^{84}$. Las condiciones para procesar los datos sensibles son similares a las exhibidas, salvo que en este caso se excluye la posibilidad de revelar los datos en pos de una función de interés público. En fin, la concurrencia de distintas manifestaciones del interés público hace que ya no pueda hablarse de excepciones absolutas tratándose de la solicitud de acceso de datos personales de terceros.

El párrafo 6 contempla exigencias adicionales para que la revelación de datos personales sea justa y legal: que "sea necesaria para los fines legítimos buscados por el controlador de datos o por el tercero [requirente] o por aquellos a quienes los datos son revelados, salvo cuando el procesamiento [de datos] sea injustificado, en algún caso particular, en razón de causar un perjuicio a los derechos, libertades o intereses legítimos del titular de los datos" ${ }^{\prime \prime 5}$.

Con el material expuesto, el Comisionado y el Tribunal han afirmado que un factor importante a considerar es si la información se refiere a la vida privada o pública de una persona, entendiendo por la primera, lo relativo al hogar, vida familiar o a sus finanzas, mientras la vida pública dice relación con el desempeño público de las personas. Conforme a ésta, se ha respaldado el acceso a los nombres, grados, funciones y decisiones de los funcionarios públicos ${ }^{86}$, como asimismo, los gastos en que han incurrido en asuntos oficiales $y$, en algunas ocasiones, información sobre los sueldos de altos funcionarios.

Así, en Corporate Officer of the House of Commons v. Information Commissioner (2007), el Tribunal se pronunció sobre una solicitud para conocer el detalle de gastos efectuados por los parlamentarios de la Cámara de los Comunes con cargo a sus asignaciones por concepto de viajes. La Cámara legislativa rechazó la solicitud esgrimiendo que se trataba de información personal, aunque el Tribunal al admitir que se trataba de información protegida por la Ley de Datos personales, dio acceso fundado principalmente en dos argumentos,

${ }^{84}$ Data Protection Act 1998 chapter 29, de 1998, Schedule 2, (5) (a), (aa), (c) y (d), (la cursiva es nuestra).

85 Data Protection Act 1998 chapter 29, de 1998, Schedule 2 (6) (1).

${ }^{86}$ Ejemplos: Comisionado de Información Pública, Decisión FS50063659 de 12 julio de 2005; FS50062124 de 25 de agosto de 2005 y FS50068973 de 24 de noviembre de 2005. Por el Tribunal de Información Pública: Lancashire County Council v Information Commissioner, EA/2006/0027 de 30 de julio de 2007 y Mr. Colin P England (1) and London Borough of Bexley (2) v. Information Commissioner, EA/2006/0060 \& 0066, de 10 de mayo de 2007. 
que responden a la siguiente pregunta: "Si es correcto distinguir entre los datos personales de la vida pública o privada de un individuo" ${ }^{87}$. La sentencia afirmó (a) que la distinción entre "la vida privada o pública del titular de datos" es pertinente, pues el propósito de publicar el detalle de las aludidas asignaciones dice relación con "el pago a funcionarios públicos en el desempeño de sus labores. Con ocasión de esta función pública es que los datos son revelados y por esto es que estimamos que tenemos interés en tales datos".

Además, (b) la revelación no causaba un perjuicio a los derechos de los parlamentarios, pues "cuando el titular de los datos cumple funciones públicas, posee cargos electivos o gasta dineros públicos, deben esperar que sus acciones públicas estén sujetas a un mayor escrutinio que en el caso de su vida privada. Este principio incluso aplica cuando algunos pocos aspectos de sus vidas privadas se entrelazan en sus vidas públicas, pero esto, en el entendido que la gran mayoría de los datos revelados dicen relación con la vida pública del titular de datos". En este caso, añade, "los datos personales revelados se relacionan con su vida pública" ${ }^{\prime 8}$ (la de los parlamentarios) antes que con su vida privada.

Finalmente, y para cumplir con la exigencia de que la revelación fuese necesaria para fines legítimos sin ocasionar un daño injustificado a los titulares de datos, sostuvo que luego de haber "considerado todos los intereses, estimamos que el interés legítimo del público supera el daño a (...) los miembros del parlamento", por lo que "II]a revelación supone una leve invasión en la privacidad de los parlamentarios atendido el contexto de su función pública y del gasto de dinero público" ${ }^{\prime \prime 9}$. Recurrido este fallo para ante la Alta Corte, ésta ratificó lo obrado por el Tribunal. Si bien comenzó afirmando que aunque "la excepción [de la FOIA] es 'absoluta', 'todas las circunstancias' deben ser analizadas para determinar si el interés público en acoger la excepción de reserva 'supera el interés público' en revelar", este fallo poco o nada añade en lo que al interés público se refiere y más bien aporta en descartar la alegación de que la revelación de la dirección residencial de los parlamentarios fuese una invasión a su privacidad ${ }^{90}$.

El caso expuesto, más que uno que pueda ser proclamado como un ejemplo en que "el derecho a la privacidad fue vencido por el derecho del público a

\footnotetext{
87 Tribunal de Información Pública, Corporate Officer of the House of Commons v. Information Commissioner and Norman Baker MP, EA/2005/0015 y 0016, de 16 de enero de 2007, párrafo. 74.

${ }^{88}$ Tribunal de Información Pública, Corporate Officer of the House of Commons v. Information Commissioner and Norman Baker MP, EA/2005/0015 and 0016, de 16 de enero de 2007, párrafos 77-78 y 79 (3).

89 Tribunal de Información Pública, Corporate Officer of the House of Commons v. Information Commissioner and Norman Baker MP, EA/2005/0015 y 0016, de 16 de enero de 2007, párrafo 93.

${ }^{90}$ Corte Real de Justicia de Londres, [2008] EWHC 1084 (Admin.), párrafos 8 y 41.
} 
saber"91, es muy ilustrativo por los distintos matices que plantea en un contexto donde lo crucial no está centrado en agudizar las tensiones provocadas entre el acceso a la información y el derecho a la vida privada, sino en ajustarlas -ambas- a la luz del interés público o bien común. En la misma línea se ha pronunciado la House of Lords cuando se ha inclinado por revelar datos médicos estadísticos, dejando fuera la individualización de los afectados ${ }^{92}$. Respecto de la pública individualización de los funcionarios públicos, los tribunales ingleses han trazado una razonable distinción entre funcionarios más importantes o menos importantes ${ }^{93}$.

La Ley española de acceso a la información -vigente a partir de este añotambién se ubica dentro de las legislaciones que contemplan una categórica separación entre el derecho de acceso y algunos aspectos especialmente resguardados por la intimidad. Así lo dice: "Si la información solicitada contuviera datos especialmente protegidos a los que se refiere el apartado 2 [y 3] del artículo $7^{\circ}$ de la Ley (...) de Protección de Datos de Carácter Personal" ${ }^{\prime 94}$, información ésta referida a "Ios datos de carácter personal que revelen la ideología, afiliación sindical, religión y creencias" o a aquellos que "que hagan referencia al origen racial, a la salud y a la vida sexual"95. Si bien la Exposición de Motivos del Anteproyecto adelantaba una absoluta delimitación entre uno y otro derecho ${ }^{96}$, la actual legislación relativizó dicha estricta separación al admitir la posibilidad de ponderación entre el interés público y los derechos afectados, eso sí, a condición que la información solicitada no contenga datos especialmente protegidos ${ }^{97}$.

\footnotetext{
91 ThOMSOn (2011), p. 36.

92 Cámara de los Lores, Common Services Agency v. Scottish Information Commissioner [2008] UKHL 47 de 9 de julio de 2008.

93 Tribunal de Información Pública, A. Roberts v. Information Commissioner and Dept. for Business, Innovation and Skills (EA/2009/0035); Robin Makin v. Information Commissioner and M. of Justice (EA/2008/0048); Creekside Forum v. Information Commissioner and Dept. for Culture, Media and Sport (EA/2008/0065).

${ }_{94}$ Ley № 19/2013, de 2013 artículo 15 № 1, agrega que "el acceso únicamente se podrá autorizar en caso de que se contase con el consentimiento expreso y por escrito del afectado, a menos que dicho afectado hubiese hecho manifiestamente públicos los datos con anterioridad a que se solicitase el acceso". Igual limitación absoluta precisa el inciso $2^{\circ}$, si la solicitud "incluyese datos especialmente protegidos a los que se refiere el apartado 3 del artículo 70 de la citada ley.

95 Ley Orgánica № 15/1999, de 1999 artículo 7º, apartado 2 y 3, respectivamente.

${ }^{96}$ Anteproyecto de Ley de Transparencia y Acceso de los Ciudadanos a la Información Pública, al respecto decía: "cierra el acceso a la información pública que contiene datos relativos a la intimidad o la vida privada de las personas, salvo que el afectado lo consienta expresamente y por escrito, o lo autorice la ley".

${ }^{97}$ Ley No 19/2013, de 2013 artículo 15 Nº 3.
} 


\subsection{Vida privada de los funcionarios públicos y libertad de expresión en la jurisprudencia nacional}

Ya que la confrontación entre el ejercicio de la libertad de informar (por y a través de medios de comunicación) y el derecho a la vida privada de quienes ejercen una función pública conduce al artículo 30 de la Ley de Prensa, constataremos la respuesta jurisprudencial dada en los casos en que se ha invocado la libertad de expresión para informar sobre hechos que serían de interés público por referirse "al desempeño de funciones públicas" y el servidor público reclamare invasión a su vida privada con ocasión de la señalada imputación. Especial atención centraremos en los criterios de interés público empleados, no sólo debido a que los tribunales superiores no han acudido a la noción de privacidad reducida y sólo excepcionalmente al TIP, sino porque de tales criterios depende en grado superlativo (también en el derecho comparado) la justificación empleada para develar legítimamente aspectos de la vida privada que afecten el desempeño de una función pública.

Aunque la jurisprudencia nacional es escasa en la materia, entre otros motivos porque la Ley de Prensa es relativamente reciente, hay un par de casos dignos de ser examinados desde la perspectiva del interés público involucrado. En el contexto de la Ley de Prensa, cabe destacar los casos "Calvo" y de la "Doctora Cordero". Si bien únicamente el primero se vincula con el ejercicio de una función pública y en ambos la acción intentada persigue hacer efectiva la responsabilidad penal por infracción al artículo 161-A del Código Penal (que sanciona la intrusión y difusión en la vida privada), los dos fallos son útiles por la noción de interés público, invocando para ello el artículo 30 de la Ley de Prensa.

En el primer caso, un individuo simula ser periodista y en coordinación con otros profesionales de un canal de televisión, se introduce en el despacho del juez Calvo y filma ocultamente el diálogo sostenido con éste a fin de obtener de su parte la confirmación de que frecuentaba un sauna gay. Entonces, dicho magistrado investigaba la comisión de delitos sexuales contra menores. Luego, la estación de televisión denunció los aludidos hechos exhibiendo imágenes en las que el juez acudía a un lugar que sería el sauna sin brindar mayores antecedentes.

Los acusados esgrimieron la concurrencia de interés público en informar sobre la asistencia del juez al sauna gay, pues tal situación lo hacía vulnerable a presiones y eventuales extorsiones en la sustanciación del proceso sobre pedofilia que investigaba. Esto demostraba, decía uno de los acusados, que la conversación entre los aludidos "carecería del carácter de privado, por cuanto en su publicidad existe interés público". El fallo de primera instancia desestimó estas afirmaciones en el entendido que la sola asistencia del juez al sauna no afectaba necesariamente sus funciones judiciales ni su comportamiento 
profesional, ya que ello no significaba que fuera homosexual ni tampoco que demandara servicios sexuales pagados. Así lo dice: "no se acreditó que Calvo hubiere concurrido al sauna gay con menores, o mantenido sexo explícito y pagado en dicho local, [por lo que] mal puede sostenerse que sea de interés público dar a conocer a la opinión pública su asistencia al sauna"98.

La Corte de Apelaciones de Santiago confirmó la sentencia apelada, descartando la existencia de interés público en el reconocimiento de que el juez asistía a un sauna gay. Un aspecto interesante del fallo es que efectúa un juicio de reproche en cuanto al empleo de medios ilícitos para obtener el fin buscado, al señalar que "no se advierte como es que estas [maniobras para tramposamente ingresar a la oficina del juez mediante cámara oculta] puedan enmarcarse dentro del concepto de interés público". . Lo reitera en el considerando sexto al afirmar que lo que "no es posible justificar" en el derecho a la libertad de información es "revelar públicamente información íntima mañosamente obtenida" 99 .

En el caso "Doctora Cordero", dos periodistas, simulando estar enfermos -y con el fin de denunciar la práctica de algunos médicos de otorgar licencias médicas irregulares- concurrieron a su consulta siquiátrica para solicitar el señalado permiso. Provistos de cámaras ocultas, grabaron la entrevista en que ella y otros profesionales otorgaban lo solicitado y luego difundieron las imágenes y el audio de la aludida conversación en un programa de televisión, sin que los afectados hubieran consentido en la grabación ni en la difusión de lo allí ocurrido.

Una de las profesionales afectadas, la doctora Cordero, interpuso querella criminal en contra de los señalados periodistas, el editor y el productor periodístico del programa que difundió las imágenes, además de una acción de responsabilidad civil. En primera instancia, aquéllos fueron condenados por infracción a los incisos primero y segundo del artículo 161-A del Código Penal, además del pago de una indemnización. Esta sentencia estimó que no cualquier

\footnotetext{
${ }_{98}$ Tercer Juzgado del Crimen de Santiago, rol № 209.909-2003 de 15 de julio de 2005, c. 25ㅇ, que añade: "La sola concurrencia del Juez Calvo a un sauna gay, si no se le hubiere dado la connotación periodística a la que se le expuso carecía de interés público puesto que, el hecho que se denunció no había afectado el desempeño de su función de juez en la causa contra Spiniak, por el contrario esta públicamente reconocido que su comportamiento como tal no ha sido cuestionado ni objetado por nadie (...)".

${ }^{99}$ Corte de Apelaciones de Santiago, rol № 21.722-2005 de 9 de mayo de 2006, c. 5: "realizar todas las maniobras para tramposamente ingresar a su oficina, obtener mediante una cámara oculta una declaración de hechos íntimos que no están vinculados con la causa que investigaba como queda demostrado de la trascripción de la misma a fs. 405, mediando datos falsos para obtenerla (mención a un video inexistente), y posteriormente difundirla en un noticiero, no se advierte como es que estas puedan enmarcarse dentro del concepto de interés público" y c. $6^{\circ}$ (los errores ortográficos corresponden al texto original).
} 
interés público justificaba la intromisión en la intimidad de la afectada: "sólo el eventual afectado, la ley o la autoridad judicial pueden justificar la conculcación de esos derechos por bienes jurídicos que el ordenamiento cautele con mayor celo, el que en la especie (el correcto uso de los beneficios de la seguridad social) no tiene la entidad de las garantías constitucionales cuya colusión se sopesa en el caso de autos ${ }^{\prime 100}$. Apelada la sentencia, fue confirmada por la Corte de Apelaciones ${ }^{101}$.

Los condenados interpusieron un recurso de casación en el fondo y la Corte Suprema lo acogió, absolviendo a los querellados, tanto de la responsabilidad penal como de la civil. El argumento principal ${ }^{102}$ que la sentencia esgrime es que la conversación no habría sido privada por el interés público en difundir el otorgamiento irregular de una licencia médica, cuya difusión es un modo de prevenir la reiteración de este tipo de conductas: "el carácter privado desaparece cuando se trata de conductas que revisten un interés público. En el caso en análisis si bien no se ha demostrado la comisión de un ilícito por los presuntos perjudicados, lo cierto es que su conducta importa al menos una transgresión a la ética por parte de profesionales de la salud que otorgaban licencias médicas falsas en desmedro de los demás cotizantes de los sistemas de salud, cuestión que reviste un interés público con mérito suficiente para ser socializada lo que permitirá en último término, el fin de una situación reprobable e inconveniente ${ }^{\prime 103}$.

Finalmente, en abono a esta hipótesis de interés público, y luego de reproducir parte del artículo 30 de la Ley de Prensa, el fallo absolutorio concluye que "[I]os hechos que se atribuyen a los inculpados se ajustan a tales circunstancias, lo que acredita la legitimidad de su actuación inserta en el ejercicio de la función periodística es aras de un interés social prevalente"104.

Mientras en el caso "Calvo", el interés público habría estado asociado a la verificación de una circunstancia que podría haber afectado la imparcialidad del juez, poniendo en entredicho su función pública de brindar justicia imparcial, en el "Doctora Cordero", en cambio, el interés público es identificado con una

\footnotetext{
100 Vigésimo Segundo Juzgado del Crimen de Santiago, rol № 3913- 2003 de 30 de abril de 2011, c. 11 ${ }^{\circ}$.

101 Corte de Apelaciones de Santiago, rol № 1781-2011 de 1 de agosto de 2012.

102 El otro argumento afirmó que las dos conductas sancionadas por el art. 161-A del Código Penal se aplican sólo cuando un tercero, ajeno a una conversación privada, la graba y luego la difunde, lo que no se habría dado, ya que los condenados fueron partícipes de una conversación privada, Corte Suprema, rol No 8393-2012 de 21 de agosto de 2013, c. $7^{\circ}$.

103 Corte Suprema, rol № 8393-2012 de 21 de agosto de 2013, c. 5 , que reitera: "no ha podido estimarse que la conversación de los periodistas con la profesional sea de carácter privado, pues se refiere a hechos que revelan irregularidades de la praxis médica verificables para ante la opinión pública".

104 Corte Suprema, rol No 8393-2012 de 21 de agosto de 2013, c. $6^{\circ}$.
} 
práctica profesional recurrente que junto con configurar "una transgresión a la ética" por parte de quienes incurren en ella, va "en desmedro de los demás cotizantes de los sistemas de salud" o del "correcto uso de los beneficios de la seguridad social", como lo expresó con precisión la sentencia de primera instancia.

Debe constatarse que en estos dos procesos, ninguno de los sentenciadores acudió al test de proporcionalidad ni tampoco al argumento de la privacidad reducida del funcionario público en el caso del juez Calvo. Asimismo, y no obstante las diferencias existentes en ambos, se advierte que el interés público es el parámetro escogido para justificar las conductas descritas en el artículo 161-A del Código Penal. Así lo ha ido reconociendo por lo demás la doctrina constitucional ${ }^{105}$ y penal ${ }^{106}$. Además, en los fallos es observado el interés público, en mayor o menor grado, como una categoría normativa cuya prevalencia sobre la vida privada se encuentra legitimada en vistas a la consecución de un bien superior -el mismo interés público- por lo que dicha justificación sólo vendrá de la mano de la libertad de expresión en la medida que mediante su ejercicio pueda promoverse u obtenerse el referido interés común.

\subsection{La vida privada de los funcionarios públicos ante la libertad de expresión en la Corte Interamericana de DD.HH.}

Sucede que en casi la totalidad de los casos pronunciados por la CIDH que han afectado a funcionarios públicos o políticos el derecho conculcado ha sido la honra antes que la vida privada ${ }^{107}$. Esto levantaba un margen razonable de duda respecto de si las consideraciones sostenidas por la Corte en dichas sentencias eran con igual intensidad extensibles al derecho a la intimidad. A modo ilustrativo, en $R$. Canese (2004) y Herrera Ulloa (2004) se señalaba que si bien las expresiones pronunciadas respecto de funcionarios públicos y políticos "deben gozar de un margen de apertura a un debate amplio respecto de

\footnotetext{
105 Meins Olivares (2000), pp. 311-312; Nogueira Alcalá (2004), pp. 155-156; Vivanco Martínez (2006), p. 348; Covarrubias Cuevas (2013), pp. 178-182 y la doctrina allí citada.

106 Novoa Monreal (1981), pp. 205-206. Asimismo: Díaz Tolosa (2007), pp. 6-7 y la doctrina penal allí citada.

107 García Ricci (2014), pp. 1056-1058, donde identifica tres casos-Herrera Ulloa vs. Costa Rica, R. Canese vs. Paraguay y Kimel vs. Argentina- que "trataban de un conflicto entre el derecho a la libertad de expresión en temas de interés público y la protección de la honra de los funcionarios públicos, de personas que ejercen funciones de naturaleza pública o de políticos", Claude Reyes y Otros, Serie C № 151, de 19 de septiembre de 2006, párrafo 91. Asimismo: Palamara vs. Chile, Serie C № 135, de 22 de noviembre de 2005, párrafo 85; Ricardo Canese vs. Paraguay, Serie C No 111, de 31 de agosto de 2004, párrafo 96; Herrera Ulloa vs. Costa Rica, Serie C № 107, de 2 de julio de 2004, párrafo 121123; y La Colegiación Obligatoria de Periodistas, Opinión Consultiva OC-5/85, Serie A № 5, de 13 de noviembre de 1985, párrafo 46.
} 
asuntos de interés público (...) es esencial para el funcionamiento de un sistema verdaderamente democrático", agregaba que esto "no significa, de modo alguno, que el honor de los funcionarios públicos o de las personas públicas no deba ser jurídicamente protegido"108. Parecía afirmarse que el interés público alcanzaba a interferir en los asuntos protegidos por la honra pero no en la intimidad.

En efecto, mientras por una parte sostenía que en estos casos el mayor escrutinio que deben soportar las personas que ejercen funciones de naturaleza pública, e incluso, aquellos particulares que "influyen en cuestiones de interés público", "no se asienta en la calidad del sujeto, sino en el carácter de interés público que conllevan las actividades o actuaciones de una persona determinada"109, paralelamente afirmaba que por la gestión pública involucrada tales personas debían suportar una "mayor tolerancia frente a afirmaciones y apreciaciones vertidas por los ciudadanos" 110 así como "un riguroso escrutinio de todas sus palabras y hechos [de un político o servidor público ] por parte de periodistas y de la opinión pública"111, enfatizando siempre que el umbral diferente se refería a una mayor aceptación de las opiniones críticas y apreciaciones subjetivas sobre la gestión pública, acogiendo en este sentido la doctrina del Tribunal Europeo de DD.HH. sobre restricciones legítimas a la libertad de expresión cuando se invoca un interés público ${ }^{112}$.

Así, por un lado se expresaba que el menor umbral de resguardo del honor es igual para todos -funcionarios públicos y particulares- en tanto unos y otros estén involucrados en "actividades de interés público", siendo éste el elemento diferenciador relevante y no la calidad del sujeto, por el otro decía que el mayor escrutinio no sólo alcanzaba a las "palabras" del servidor público sino

108 Corte Interamericana de Derechos Humanos, Herrera Ulloa vs. Costa Rica, Serie C No 107, de 2 de julio de 2004, párrafo 128 (por ambas citas), y Ricardo Canese vs. Paraguay, Serie C No 111, de 31 de agosto de 2004, párrafo 100, en cuanto a que el honor de las personas mencionadas debe igualmente ser jurídicamente protegido.

${ }^{109}$ Corte Interamericana de Derechos Humanos, Herrera Ulloa vs. Costa Rica, Serie C No 107, de 2 de julio de 2004, párrafo 129, p. 71, complementado en Ricardo Canese vs. Paraguay, Serie C № 111, de 31 de agosto de 2004, párrafo 103, p. 65.

${ }^{110}$ Corte Interamericana de Derechos Humanos, Kimel vs. Argentina, Serie C № 177 de 2 de mayo de 2008, párrafo 89.

111 Corte Interamericana de Derechos Humanos, Herrera Ulloa vs. Costa Rica, Serie C No 107, de 2 de julio de 2004, párrafo 125, p. 70.

112 Corte Interamericana de Derechos Humanos, Herrera Ulloa vs. Costa Rica, Serie C № 107, de 2 de julio de 2004, párrafos 121 y 125, pp. 69-70, donde consta la referencia a: Corte Europea de Derechos Humanos, The Sunday Times v. United Kingdom, Application No 6538/74, de 26 de abril de 1979, párrafo 59; Barthold v. Germany, Application № 8734/79, de 25 de marzo de 1985, párrafo 59; Dichand and others v. Austria, Application № 29271/95, de 26 de febrero de 2002, párrafo 39, y Lingens vs. Austria, Application № 9815/82, de 8 de julio de 1986, supra nota 91, párrafo 42. 
también a sus "hechos", con lo que surgía la duda de si el interés público en promover la opinión crítica sobre la conducta funcionaria (honra) se extendía también a la conducta personal (vida privada) del funcionario en tanto ella incidiera en asuntos de interés público, entendiendo por éstos aquellos en que se "compromete a la sociedad en su conjunto, incide sobre la marcha del Estado, afecta intereses o derechos generales, o le acarrea consecuencias importantes para la comunidad"113. Aunque la CIDH entregaba lineamientos bastante claros respecto de la noción de asunto de interés público, permanecía el margen de duda ya señalado en otros pasajes de los citados fallos ${ }^{114}$.

Esta incertidumbre es disipada en Fontevecchia v. Argentina (2011), caso en el que el director y editor de la revista Noticias fueron condenados civilmente por la Corte Suprema argentina por violación a la intimidad del entonces Presidente de la Nación. Una de las publicaciones consideradas lesivas informaba de la existencia de un "presunto hijo natural" del presidente Menem con una diputada, y también acerca de la entrega de cuantiosas sumas de dinero y de regalos que la autoridad habría dado a su hijo como a la madre del niño, además de la presunta existencia de gestiones y favores económicos y políticos al entonces esposo de la diputada.

Pues bien, la duda es despejada al afirmarse que el "Tribunal considera que los estándares que ha utilizado respecto a la protección de la libertad de expresión en los casos de los derechos a la honra y a la reputación son aplicables, en lo pertinente, a casos como el presente". Tales criterios "son: a) el diferente umbral de protección de los funcionarios públicos, más aún de aquellos que son elegidos popularmente, respecto de las figuras públicas y de los particulares, y b) el interés público de las acciones que aquellos realizan". En cuanto al primer estándar agrega que tratándose del "Presidente de la Nación (...) estaba sujeto al mayor escrutinio social, no solo sobre sus actividades oficiales o el ejercicio de sus funciones sino también sobre aspectos que, en principio, podrían estar vinculados a su vida privada pero que revelan asuntos de interés público"115.

113 Corte Interamericana de Derechos Humanos, Herrera Ulloa vs. Costa Rica, Serie C No 107, de 2 de julio de 2004, párrafo 23, p. 7 (concurrencia del Juez Sergio García R.), reiterado en Ricardo Canese vs. Paraguay, Serie C No 111, de 31 de agosto de 2004, párrafo 98, pp. 63-64, y en Tristán Donoso v. Panamá, Serie C No 193, de 27 de enero de 2009, párrafo 121.

114 Corte Interamericana de Derechos Humanos, Ricardo Canese vs. Paraguay, Serie C № 111, de 31 de agosto de 2004, párrafo 103, p. 65: "[a]quellas personas que influyen en cuestiones de interés público se han expuesto voluntariamente a un escrutinio público más exigente y, consecuentemente, en ese ámbito se ven sometidos a un mayor riesgo de sufrir críticas, ya que sus actividades salen del dominio de la esfera privada para insertarse en la esfera del debate público"

115 Corte Interamericana de Derechos Humanos, Fontevecchia v. Argentina, Serie C No 238, de 29 de noviembre de 2011, párrafos 59-60, p. 21. 
Sobre el segundo criterio, dijo que la información se ajustaba a la noción de IP ya formulada ("compromete a la sociedad en su conjunto, incide sobre la marcha del Estado, afecta intereses o derechos generales...") ya que "se relaciona con la integridad de los funcionarios y, aún sin necesidad de determinar si se hizo uso de fondos públicos para fines personales, la disposición de sumas cuantiosas y regalos costosos por parte de un Presidente de la Nación, así como con la eventual existencia de gestiones o interferencias en una investigación judicial, son cuestiones sobre las cuales existe un legítimo interés social en conocerlas", constituyendo también una manifestación del control público sobre hechos como los denunciados ${ }^{116}$.

Sentados ambos criterios, se quiso examinar la licitud de la sentencia judicial aplicada por el Estado reclamado según las exigencias del test de proporcionalidad. Al efecto estimó que era legal, perseguía un fin legítimo (resguardar la intimidad), era idónea (servía para salvaguardad el bien jurídico que se quiere proteger). En cuanto al requisito de ser necesaria (existencia de una necesidad social imperiosa que justifique la restricción), el fallo da a entender que no lo es por ser de interés público la información develada, lo cual hace innecesaria -según los dos estándares exhibidos- la restricción de una libertad de expresión legítimamente ejercida ${ }^{117}$.

Dos factores adicionales, entre otros, son subrayados. El primero dice relación con los actos propios del señor Menem respecto de publicaciones anteriores sobre el mismo asunto, lo cual da a entender que los aspectos de la intimidad reclamados no sólo habían sido de algún modo dispuestos por el titular del derecho sino que el asunto ya se encontraba en la esfera de discusión públi$\mathrm{ca}^{118}$. El segundo enfatiza que las fotos publicadas sobre el tema, aparte de dar credibilidad a los hechos de interés público informados, no fueron obtenidas por medios "de intrusión" o "tomadas de cualquier otra manera subrepticia"119.

Habiendo considerado que las publicaciones realizadas "respecto del funcionario público electivo de más alto rango del país trataban sobre asuntos de interés público, que los hechos al momento de ser difundidos se encontraban en el dominio público y que el presunto afectado con su conducta no había

116 Corte Interamericana de Derechos Humanos, Fontevecchia v. Argentina, Serie C No 238, de 29 de noviembre de 2011, párrafos 47 y 51, pp. 21-22.

117 Corte Interamericana de Derechos Humanos, Fontevecchia v. Argentina, Serie C No 238, de 29 de noviembre de 2011, párrafos 54-61., pp. 20-21.

118 Corte Interamericana de Derechos Humanos, Fontevecchia v. Argentina, Serie C No 238, de 29 de noviembre de 2011, párrafos 64-65, p. 22.

119 Corte Interamericana de Derechos Humanos, Fontevecchia v. Argentina, Serie C No 238, de 29 de noviembre de 2011, párrafo 69, p. 24: "tales como el ingreso físico a un lugar restringido o el uso de medios tecnológicos que posibiliten la captación de imágenes a distancia". 
contribuido a resguardar la información cuya difusión luego objetó", la CIDH, concluyó que "no hubo una injerencia arbitraria en el derecho a la vida privada del señor Menem" y que "la medida de responsabilidad ulterior impuesta (...) fue innecesaria en relación con la alegada finalidad de proteger el derecho a la vida privada"120.

Aunque ya fuera del ámbito del artículo 30 de la Ley de Prensa, es posible constatar en la jurisprudencia de la CIDH sobre libertad de expresión e intimidad y honra, que la prevalencia del primero sobre el segundo se produce toda vez que por su ejercicio se informe sobre asuntos de interés público.

\subsection{La privacidad de los funcionarios públicos frente a la libertad de expresión en algunos casos de derecho comparado}

En New York Times v. Sullivan (1964) se sentó un criterio en virtud del cual los comentarios vertidos sobre la "conducta oficial" de un funcionario público gozan de una fuerte protección que sólo puede ser revertida si el afectado probare la concurrencia de "real malicia", esto es, de la falsedad consciente de lo publicado o del notorio desprecio sobre su falsedad o veracidad ${ }^{121}$. Si bien el caso no se refiere a la vida privada del ofendido sino que a su reputación, el estándar desarrollado a partir de dicho fallo ha sido empleado en otros casos para denegar resguardo a la vida privada de ciertas personas que no eran funcionarios públicos sino figuras públicas o particulares que se vieron involucradas en sucesos de connotación pública.

Confrontadas desde entonces la libertad de expresión con el derecho a la honra (y la intimidad en algunos casos), la regla invariablemente sostenida por la Corte Suprema federal ha sido acudir a un tipo rígido de ponderación, denominado definitional balancing o jerarquización, que aborda las colisiones de derechos por medio de categorías previas y abstractas que establecen $a b$ initio la primacía del bien estimado jerárquicamente superior, lo que otorga a ciertos derechos un estatus "preferido" o "institucional" frente a otros que no les queda más remedio que ceder ante aquéllos ${ }^{122}$.

Junto al estándar de la real malicia, dicho tribunal adoptó, en ciertas ocasiones, una versión similar al argumento del menor resguardo de las figuras y

${ }^{120}$ Corte Interamericana de Derechos Humanos, Fontevecchia v. Argentina, Serie C No 238, de 29 de noviembre de 2011, párrafo 71, p. 25.

121 Corte Suprema de Estados Unidos, New York Times v. Sullivan (1964), 376 U.S. 254, 276, en que se admite la reparación de daños en caso de probarse que las expresiones hayan sido efectuadas con "real malicia", esto es, con conocimiento de la falsedad de la misma o con un descuido temerario acerca de su falsedad o veracidad.

122 Aleinikoff (1987), p. 948; Serna y Toller (2000), pp. 3-19. 
funcionarios públicos frente al ejercicio de la libertad de expresión, bajo la denominación de teoría de la asunción del riesgo ${ }^{123}$. Debe señalarse, sin embargo, que en tales casos -Butts (1967) ${ }^{124}$, Rosenbloom (1971) ${ }^{125}$ y Gertz (1974) ${ }^{126}$ - el aludido argumento no fue el decisivo y ningún funcionario público fue tampoco el afectado. En Garrison (1964) $)^{127}$ y Rosemblat (1966) ${ }^{128}$, de los pocos casos en que se explicitó la doctrina de la real malicia respecto de la intimidad de un funcionario público, ninguna aplicación cupo a la hipótesis de la asunción del riesgo de las figuras públicas.

Si a lo anterior se observa que el estándar de la real malicia fue concebido para escudar la diseminación de falsedades difamatorias, no la develación o información de hechos o conductas verdaderas (condición esencial de aquello que está protegido por la vida privada), es discutible que pueda afirmarse tan categóricamente que la Corte haya sostenido en New York Times v. Sullivan un criterio como el de la menor esfera de intimidad de los funcionarios públicos. Esto, sin perjuicio del embate de que ha sido objeto este criterio por parte de la misma Corte ${ }^{129}$ y de la doctrina ${ }^{130}$, al estimar que las premisas bajo las cuales se erige son aplicables más bien al honor que a la privacidad ${ }^{131}$. A modo de ejemplo e ilustrando la impropiedad de aplicar el aludido criterio, Barendt ha dicho que la "aplicación de un estricto estándar de libertad de expresión como aquel de New York Times conduciría al inaceptable resultado que sería prácticamente imposible para los políticos y las celebridades proteger su privacidad"132.

${ }^{123}$ Corte Suprema de Estados Unidos, Curtis Publishing Co. v. Butts, 388 U.S. 130, 164 (1967); Gertz v. Robert Welch, 418 U.S. 323, 344, 363(1974): "Quienes deciden participar en la esfera pública asumen voluntariamente la reducción de su vida privada en comparación con quienes permanecen en el anonimato" y "los personajes públicos tienen mayor acceso de para enfrentar a la prensa o para contrarrestar la información perjudicial".

124 Corte Suprema de Estados Unidos, Curtis Publishing Co. v. Butts, 388. U.S. 130, 154 (1967).

125 Corte Suprema de Estados Unidos, Rosenbloom v. Metromedia, Inc. 403 U.S. 29, 34 (1971).

126 Corte Suprema de Estados Unidos, Gertz v. Robert Welch, 418 U.S. 323, 325-326 (1974).

127 Corte Suprema de Estados Unidos, Rosenblatt v. Baer, 383 U.S. 75, 76 (1966).

${ }^{128}$ Corte Suprema de Estados Unidos, Garrison v. Lousiana 379 U.S. 74, 77 (1964).

129 Corte Suprema de Estados Unidos, Rosenbloom v. Metromedia, Inc. (1971), 403 U.S. 29, 46, el juez Brennan dijo que idea de la asunción del riesgo debía ser fuertemente objetada, pues favorecía "producir el paradójico resultado de aguar la discusión de asuntos de interés público o general por estar involucrados ciudadanos privados, mientras otorgaría incentivo constitucional a la discusión de aspectos de las vidas de las 'figuras públicas' que no se encuentran en el ámbito de interés público o general".

130 Nimmer (1968) p. 961 y Marshall y Gilles (1994), nota 177 en pp. 202-203, a modo ejemplar.

131 Un desarrollo más amplio en Covarrubias Cuevas (2013) pp. 248-253.

132 Barendt (2005), p. 244. 
Pareciera que -en consonancia con los pasajes más relevantes del caso ${ }^{133}-$ el verdadero interés de la Corte Suprema norteamericana fue más bien amparar la libertad de expresión para fortalecer la discusión sobre asuntos de interés público cuando un funcionario público ha sido el afectado por su conducta oficial, pero este criterio dista bastante de algo similar a la idea de la intimidad reducida de los funcionarios públicos.

Reveladora en este sentido puede ser la jurisprudencia de la Suprema Corte de la Nación argentina sobre la real malicia. La adopción de esta doctrina por parte de dicha magistratura es un asunto bastante exento de polémica ${ }^{134}$ independiente de su variabilidad y evolución. También es pacífico afirmar que dicho criterio ha sido aplicado en casos de tensión entre el derecho a la honra y la libertad de expresión antes que en aquellos en que ésta confronta a la vida privada ${ }^{135}$. De hecho, en los casos de intromisión en la intimidad no se ha aplicado la real malicia. Ilustrativo es Ponzetii de Balbín (1984), "un fallo trascendente que nutre a diversos pronunciamientos posteriores ${ }^{\prime \prime 136}$, referido a la publicación en una revista de una fotografía del afamado doctor Balbín cuando se encontraba internado en la sala de terapia intensiva de una clínica.

Entonces, la Corte Suprema de la Nación afirmó que "en el caso de personajes célebres cuya vida tiene carácter público o personajes populares, su actuación pública o privada puede divulgarse en lo que se relacione con la actividad que les confiere prestigio o notoriedad y siempre que lo justifique el interés general. Pero ese avance sobre la intimidad no autoriza a dañar la imagen pública o el honor de estas personas y menos sostener que no tienen un sector o ámbito de vida privada protegida de toda intromisión"137. Ni aquí ni tampoco posterior-

\footnotetext{
133 Corte Suprema de Estados Unidos, New York Times v. Sullivan (1964), 376 U.S. 254, 276, 270, en que se entendió que la publicación que criticaba la conducta de un funcionario público debía estimarse una especie de actividad constitucionalmente protegida por la primera enmienda por cuanto tales imputaciones, aunque fueran desdorosas y falsas, eran consistentes con la libertad de expresión, cuyo objeto es asegurar "el principio de que el debate sobre los asuntos públicos debe ser desinhibido, robusto y abierto", propósito para el cual el ataque "vehemente, punzante, y a veces desagradablemente mordaz respecto de la conducta funcionaria y gubernamental" resultaba indispensable.

134 Pizarro (1997), p. 10 y BazÁn (1998), pp. 1-8; a modo ejemplar.

135 Borgarello y Juárez Centeno (2003), p. 94. Refiriéndose a la real expresan que se trata de una doctrina en la que "se distinguen dos clases de protección al honor de las personas" (no la vida privada) y los casos allí exhibidos respaldan tal afirmación.

136 BAZÁn (2008), p. 117.

137 Corte Suprema de la Nación Argentina, Ponzetti de Balbín con Editorial Atlántida S.A., de 11 de diciembre de 1984, c. 9.
} 
mente la Corte trasandina ha empleado la doctrina de la real malicia en casos de invasión a la vida privada de figuras o funcionarios públicos ${ }^{138}$.

Por otra parte, cabe considerar que en las ocasiones en que la Corte de EE.UU. ha sacrificado la vida privada de los funcionarios públicos, tales injerencias han afectado la garantía constitucional de no padecer "registros ni decomisos arbitrarios"139 -único ámbito de la intimidad expresamente reconocido por la Carta norteamericana- que aspectos vinculados con la vida privada personal o familiar del funcionario público o relativos a la información personal de éstos, en registros de acceso al público o en virtud del estándar de la real malicia. Lo que ha estado en juego aquí ha sido la intimidad del funcionario en su lugar de trabajo frente a las potestades de investigación del empleador ${ }^{140}$ antes que su privacidad de cara a la libre expresión y el derecho de acceso. Y en los casos en que estos derechos han prevalecido a la intimidad del funcionario público, la Corte ha dicho que el criterio adoptado es casuístico ("case-by-case basis"141), por lo que no es posible extraer de ellos conclusiones generales.

En fin, el modo en que la Corte Suprema norteamericana ha brindado a la libertad de expresión un poder desequilibrante frente a otros derechos como la honra, ha sido acudiendo a una jerarquización apriorística antes que a un balanceo casuístico, y el efecto expansivo de la doctrina de New York Times v. Sullivan no necesariamente ha de hacerse extensivo a la vida privada de los funcionarios públicos. Por último, en los contados casos en que la intimidad se ha visto amagada a manos de la libertad de expresión, ninguna participación relevante ha cabido a la versión ya señalada de la noción de la intimidad reducida de los funcionarios o figuras públicas.

En España, cuando se ha confrontado el derecho a la intimidad de personas que poseen "proyección pública" (particulares que desempeñan una función de relevancia) o de "personas públicas" (ejercen la función representativa o la administración del poder público) con la libertad de expresión, el Tribunal

138 BAZÁn (2008), pp. 130-137 y FloRes (2006), p. 320, en que afirma que "no se aplica el estándar de protección atenuada del honor" (no de la vida privada) cuando los actores son simples particulares.

139 Constitución de Estados Unidos, Enmienda 4a, referido principalmente al "derecho de los habitantes de que su persona, domicilio, papeles y efectos estén libre de registros e incautaciones arbitrarias".

140 El criterio ha sido que si el empleador quiere efectuar un sumario administrativo en un ámbito en el que el empleado público posee una expectativa de privacidad, no necesita autorización judicial para la inspección, siempre que la invasión sea razonable en su "sospecha y alcance", LeE (2005), pp. 111129. A veces, la Corte ha dicho que el alcance de la investigación sumaria es tan acotado que no cabe aplicar la garantía constitucional, DAMmeIER (2012), pp. 301 y ss.

${ }^{141}$ Corte Suprema de Estados Unidos, O'Connor v. Ortega (1987) 480 U.S. 709, 715, 732-33: "la determinación de si los empleados públicos tienen o no una expectativa razonable de privacidad, debe ser resuelta bajo un criterio caso a caso ya que las condiciones laborales (...) varían considerablemente de un empleado público a otro". 
Constitucional ha dicho que si bien uno de los requisitos de la preeminencia de esta libertad por sobre la intimidad está determinado por la calidad de las personas que intervienen (reconociendo el menor resguardo de la intimidad en estos casos), junto con ello ha exigido un requisito material de que "la información verse sobre asuntos en los que por razón de su objeto resulta de interés colectivo o general"142. Esto es muy interesante, pues da cuenta que la exigencia subjetiva de la calidad de las personas involucradas no se justifica en sí misma, por lo que es accesoria respecto de la exigencia material consistente en la concurrencia de un interés público ${ }^{143}$. Así, la sola constatación de verse involucrado un funcionario público -sin la verificación del interés público- parece no tener la aptitud para que la libertad de expresión, más bien el interés público que en ocasiones trae aparejado, prime sobre el derecho a la intimidad. Una versión similar del criterio de intimidad reducida ha sido adoptada en ocasiones por nuestros tribunales ${ }^{144}$.

Interesante es contrastar los casos precedentemente expuestos con otros en que el TEDH asume la análoga relevancia de la libertad de expresión como fundamento básico para la sociedad democrática y para el desarrollo individual y también para la diseminación de ideas e informaciones que incluso puedan resultar chocantes y perturbadoras, y cuyas limitaciones -reconocidas en el artículo 10 de la Convención europea- deben ser estrictamente argumentadas y su necesidad convincentemente establecida ${ }^{145}$. Paralelamente ha dicho que: "Aunque la prensa no debe traspasar determinados límites, en particular la protección de la reputación y derechos de terceros, su deber consiste en difundir-de

${ }_{142}$ Tribunal Constitucional Español, rol № 192/1999 de 25 de octubre de 1999, FJ 7; rol № 8/2001 de 27 de Junio de 2001, FJ 6; rol № 54/2004 de 15 de abril de 2004, FJ 3, a modo ejemplar. Un análisis más detallado de estos y otros fallos en Covarrubias Cuevas (2013), pp. 134-154. Asimismo González Cifuentes (2011), pp. 153-171.

143 En sentido análogo, González Cifuentes (2011), pp. 151-152, quien señala que "identificamos a este requisito [del estatus de la persona] como 'exigencia acumulativa'" del "criterio fundamental" del "interés general que encierran los datos difundidos".

144 Una modalidad de esta idea se encuentra en Luz María Virginia de Lourdes Donoso Arteaga con Revista Caras (1998) c. $3^{\circ}$ y $9^{\circ}$ (revocado por la C. Suprema, 3 de noviembre de 1998) en que se adoptó una valoración diferenciada entre persona pública y la privada, al afirmar que la víctima "tuvo una vida común y corriente. No era autoridad pública ni política, como tampoco realizaba alguna actividad que pudiera interesar a la comunidad" [caso en el cual] respecto de sus actuaciones "el derecho a informar, sin censura previa, pueda adquirir otras connotaciones", citadas en COVARRUBIAS Cuevas (2013), p. 393. Parte de este argumento, también en Corte Suprema, Enrique van Rysselbherge, Fallos del Mes 488, p. 1354.

${ }^{145}$ Corte Europea de Derechos Humanos, Handyside v. the UK, Application N ${ }^{\circ}$ 5493/72 de 7 de diciembre de 1976, párrafo 49 Series A № 24; Editions Plon v. France, Application No 581485/00 de 18 de agosto de 2004, párrafo+ 42, ECHR 2004; Lindon, Otchakovsky-Laurens y July v. France [GC], Application No 21279/02 y 36448/02 de 22 de octubre de 2007, párrafo 45, ECHR 2007, a modo ilustrativo. 
un modo consistente con sus obligaciones y responsabilidades-información e ideas sobre asuntos de interés público"146.

Con lo anterior como telón de fondo, se resolvió el caso Mitterrand (2004), referido a la publicación de un libro -escrito por el médico del ex presidente- que relataba que al entonces Premier galo se le había diagnosticado un cáncer a los pocos meses de ser electo por primera vez y cómo ello había sido ocultado al público. El TECH reconoció que si bien el texto era un asunto de interés público, en particular, "ser informado sobre cualquier enfermedad grave padecida por un jefe de Estado, y el tema acerca de si una persona que sabía que estaba seriamente enferma era apta para asumir la más alta magistratura de la nación", estimó que la orden judicial provisional impidió la distribución del libro fue "'necesaria en una sociedad democrática' para proteger los derechos del Presidente Mitterrand y sus familiares"147.

Hechos claves para estimar que la interferencia en la libertad de expresión fue "proporcionada" a fin de evitar a la viuda y a los familiares el agravamiento del dolor que la publicación del texto supuso, fueron que la orden judicial fue expedida a los pocos días de la muerte del ex mandatario y que la medida fue adoptada temporalmente (por un mes) ${ }^{148}$. Consecuente con ello es que el TEDH consideró que la orden judicial adoptada con posterioridad violaba la libertad de expresión, puesto que además de decretar una prohibición permanente a la distribución del libro, dispuso el pago de una indemnización a la empresa editora. Además, el resguardo de la confidencialidad ya no podía ser una exigencia determinante cuando el texto se encontraba diseminado en internet y había sido objeto de comentarios de prensa ${ }^{149}$.

Otros casos resueltos por el TEDH y por la Cámara de los Lores, no obstante referirse a figuras públicas que no son funcionarios, son de vivo interés, como observaremos enseguida, en lo que dice relación con los temas del presente trabajo. En Von Hannover (2005), una sala del TEDH sostuvo que los tribunales alemanes habían infringido la vida privada de la Princesa Carolina de Mónaco. Afirmó que los medios habían publicado fotos de la aludida para

${ }^{146}$ Corte Europea de Derechos Humanos, Bladet Tromsø and Stensaas v. Norway [GC], Applicaton № 21980/93 de 20 de mayo de 1999, párrafos 59 y 62, ECHR 1999, y Pedersen and Baadsgaard v. Denmark [GC], Application No 49017/99 de 17 de diciembre de 2004, párrafo 71, ECHR 2004, a modo ejemplar.

147 Corte Europea de Derechos Humanos, Editions Plon v. France, Application No 581485/00 de 18 de agosto de 2004, párrafo 48, ECHR 2004.

${ }^{148}$ Corte Europea de Derechos Humanos, Editions Plon v. France, Application No 581485/00 de 18 de agosto de 2004, párrafo 47, ECHR 2004.

${ }_{149}$ Corte Europea de Derechos Humanos, Editions Plon v. France, Application No 581485/00 de 18 de agosto de 2004, párrafos 53-55, ECHR 2004. 
satisfacer la curiosidad, pues no se referían al ejercicio público de sus funciones como Princesa sino a su vida personal y familiar ${ }^{150}$. Añadió que la difusión de fotografías personales, aun de figuras públicas, pueden afectar negativamente la vida privada ${ }^{151}$.

En lo fundamental, el TEDH rechazó el argumento de los tribunales alemanes en cuanto a que la Princesa era una "figura pública par excellence", por lo que debía soportar mayores invasiones a la intimidad que otros ${ }^{152}$. El abandono de esta tesis por parte de la judicatura alemana y su focalización en si la información era o no de interés público, junto con las circunstancias del caso, contribuyó a que el TEDH llegara a la conclusión opuesta en Von Hannover $(2012)^{153}$, referido a otras fotos que involucraban a la misma princesa y a su familia.

EI TEDH distinguió cinco criterios para resolver la tensión entre la libertad de expresión y la vida privada: (a) la contribución a un debate de interés general, (b) cuán conocida es la persona afectada y cuál es el tema del reportaje, (c) la conducta previa del afectado, (d) contenido, forma y efectos de la publicación y, (e) las circunstancias en las que las fotografías fueron obtenidas. Sobre el primer criterio dijo que si bien lo que es de interés general depende de los hechos del caso, estimó ilustrativo señalar que tal interés ha sido reconocido "no solo cuando una publicación se refiere a asuntos políticos o a crímenes, sino también cuando está referido a asuntos artísticos o deportivos (...) aunque las rumoreadas las dificultades maritales del Presidente de un país o los problemas financieros de un cantante famoso no fueron considerados como asuntos de interés general" ${ }^{\prime 154}$.

Respecto al segundo criterio, efectuó dos subdistinciones: a) que "el rol o función de la persona afectada y la naturaleza de las actividades que son objetos del reportaje o foto es otro criterio importante vinculado con el anterior", por lo que "debe distinguirse entre los individuos privados y las personas que actúan

150 Corte Europea de Derechos Humanos, Von Hannover v. Germany, Applicarion № 59320/00 de 24 de junio de 2004, párrafos 63-64, ECHR 2005.

151 Para una visión sistemática del caso en la perspectiva del derecho a la vida privada como límite al ejercicio de la libertad de expresión, véase LASAGABASTER (2009), pp. 543-546.

152 Barendt (2006), p. 21.

153 Corte Europea de Derechos Humanos, Von Hannover v. Germany No 2, Application No 40660/08 y 60641/08 de 7 de julio de 2012, párrafo 78, ECHR 2012, dice que el Tribunal Federal Alemán da cuenta que ha "abandonado tal concepto, cambiándolo por uno nuevo, que brinda un resguardo (gradualizado) según el cual era necesario exhibir, respecto de cada foto, si había un interés en publicarla (...) determinando si la publicación contribuía a un debate de interés público". La relevancia de este aspecto es destacado en las conclusiones del fallo, párrafo 125.

154 Corte Europea de Derechos Humanos, Von Hannover v. Germany No 2, Application No 40660/08 y 60641/08 de 7 de julio de 2012, párrafos 108-110, ECHR 2012. 
en un contexto público, como las figuras políticas o públicas. Por tanto, mientras un individuo privado desconocido puede pretender protección a su derecho a la vida privada, no puede decirse lo mismo respecto de las figuras públicas", (b) "Debe llevarse a cabo una distinción fundamental entre reportear hechos capaces de contribuir a un debate (...) vinculado al ejercicio de las funciones públicas de los políticos, por ejemplo, y reportear detalles de la vida privada de un individuo que no ejerce tales funciones".

Agregó que "mientras en el primer ejemplo, la prensa desempeña su rol como 'público guardián' de la democracia por medio de la diseminación de información e ideas sobre asuntos de interés público, tal rol se observa menos importante en el segundo ejemplo. Análogamente, aunque en ciertas especiales circunstancias el derecho a ser informado pueden extenderse incluso a aspectos de la vida privada de las figuras públicas, especialmente cuando están involucrados políticos, esto no ocurre -a pesar que la persona afectada sea muy conocida- cuando las fotos y los comentarios anexos a ella se refieren exclusivamente a detalles de la vida privada y tienen el único fin de satisfacer la curiosidad"155.

Al aplicar los criterios expuestos, el TEDH, estimó que aunque algunas fotos no aportaban nada a la discusión pública, el artículo y las fotos "referidas a la enfermedad que afectaba entonces al Príncipe Rainiero III (...) y la conducta de los miembros de su familia durante tal enfermedad"156 sí contribuían a un debate de interés general sobre el rol de la familia real de Mónaco, por lo que apoyó lo resuelto por los tribunales alemanes en cuanto a que no hubo infracción al derecho a la vida privada de los reclamantes.

El caso Campbell (2004) es la decisión más importante de los últimos años entre la vida privada de una celebridad y la prensa, pronunciada por la Cámara de los Lores ("los Lores"). La modelo Naomi Campbell demandó al periódico que había publicado una serie de artículos revelando detalles de su tratamiento contra la adicción de drogas y exhibiendo fotografías en que salía de Narcóticos Anónimos. Por amplia mayoría, los Lores estimaron que las publicaciones invadían la vida privada de la afectada. Uno de los aspectos de interés es que la mayoría de los sentenciadores asumieron que ninguno de los derechos confrontados -libertad de expresión y vida privada- tenían prioridad anticipada

155 Corte Europea de Derechos Humanos, Von Hannover v. Germany No 2, Application No 40660/08 y 60641/08 de 7 de julio de 2012, párrafo 110, ECHR 2012.

156 Corte Europea de Derechos Humanos, Von Hannover v. Germany N² 2, Application No 40660/08 y 60641/08 de 7 de julio de 2012, párrafo 117, ECHR 2012, dice que un factor importante fue también constatar que "había una íntima vinculación entre la foto y el evento descrito en el artículo". 
sobre el otro, haciendo suya la Resolución de la Asamblea Parlamentaria del Consejo Europeo ${ }^{157}$.

Todos los Lores, incluso los dos disidentes, concordaron en esto, pero la Baronesa Hale fue particularmente clara en este punto $^{158}$, agregando que los derechos son de "igual importancia", el relativo peso que tienen dependería a la postre de la "justificación para intervenir o restringir cada uno de aquellos derechos; y de la aplicación del test de proporcionalidad a cada uno". Agrega que dado que "cada uno es un derecho fundamental, evidentemente hay una 'necesidad social dominante' para protegerlos", por lo que "la proporcionalidad en la interferencia con uno tiene que balancearse con la proporcionalidad en la restricción del otro" derecho ${ }^{159}$.

Es destacable observar dos aspectos prácticamente unánimes en este caso: primero, que ambos derechos son de igual relevancia no existiendo preferencia apriorística en ninguno de ellos, por lo que la interferencia debe ser justificada no sólo en la libertad de expresión sino también respecto de la vida privada ${ }^{160}$. En segundo lugar, que si bien en muchas ocasiones resueltas por esta instancia judicial, la proporcionalidad no es tan claramente aceptada ${ }^{161}$, en cualquier caso, la casi totalidad no admite la exigencia de proporcionalidad en estricto sentido $^{162}$, según la fórmula adoptada por algunos países del derecho continen-

157 Cámara de los Lores, Campbell v. MGN Ltd [2004] UKHL 22 de 6 de mayo de 2004, 2 AC 457, párrafo 138, cita el párrafo 10 de la referida resolución: "Estos derechos no son absolutos ni tampoco tienen un orden jerárquico, ya que son de igual importancia".

158 BARENDT (2006), p. 22.

159 Cámara de los Lores, Campbell v. MGN Ltd [2004] UKHL 22 de 6 de mayo de 2004, 2 AC 457, párrafos 140-141.

160 Algunos autores complementan este argumento adhiriendo a la idea de que, al igual que la libertad de expresión, "Ios derechos a la intimidad personal o, incluso, a la autodeterminación informativa, tienen una importancia que trasciende el ámbito meramente individual, alcanzando una dimensión social indispensable para asegurar el respeto de la dignidad y libertad de la persona, que también constituye fundamento insoslayable de un régimen democrático", BAZÁN (2008), p. 112 y EGUIGUREN Praeli (2004), p. 22.

161 Mientras Lord Hoffman (disidente) ve el test centrado en cuidar que la restricción de un derecho en pos del bien resguardado por el otro derecho sea proporcional a la necesidad reclamada en vista al interés público, la Baronesa Hale la estima que al existir un interés público en el resguardo de ambos derechos por igual, el test de proporcionalidad no es pertinente aquí, pues supondría aplicarlo al motivo que justifica la interferencia de uno y otro derecho, lo que llevaría a ponderar el resultado de un test con el del otro test, Cámara de los Lores, Campbell v. MGN Ltd [2004] UKHL 22 de 6 de mayo de 2004,2 AC 457, párrafo 55 y 140, respectivamente.

162 En Cámara de los Lores, Campbell v. MGN Ltd [2004] UKHL 22 de 6 de mayo de 2004,2 AC 457, párrafo 113, Lord Hope es el único que sostiene que debe verificarse si la publicación "persigue un fin legítimo y si el beneficio obtenido por si difusión es proporcional al daño que pueda causar su interferencia en el derecho a la vida privada". 
tal, y el test se centra básicamente en que la exigencia de necesidad se aplique proporcionadamente (con moderación) ${ }^{163}$. Por otra parte, la idea de la intimidad reducida de las figuras públicas ni siquiera es considerada.

Parece claro que los factores relativos a la privacidad reducida de los funcionarios o figuras públicas y el test de proporcionalidad palidecen frente a la relevancia predominante del interés público ${ }^{164}$. Dado que el tema crucial es si la información publicada contribuye a un debate sobre asuntos de interés público, resta reflexionar acerca de qué tipo de información privada es la que pone en entredicho el ejercicio de la función pública ${ }^{165}$ como un aspecto del interés público o bien común. Los criterios aquí expuestos servirán como punto de partida para enjuiciar críticamente el empleo de dicho criterio por los órganos que ejercen jurisdicción. Sobre este último aspecto esperamos referirnos en un próximo artículo.

\section{4. ¿Qué criterios pueden observarse en la relación precedentemente expuesta entre la vida privada del funcionario público y el ejercicio del derecho de acceso a la información?}

Si bien el derecho a la vida privada o ciertas manifestaciones del mismo (datos personales) han sido reconocidas -en Inglaterra, Chile y España- como excepciones absolutas al derecho de acceso a la información, ello no ha impedido, con grados de variabilidad, según el caso, que la información privada quede necesariamente fuera del alcance del derecho de acceso, lo cual depende en buena medida de la configuración legislativa y la interpretación judicial con que es concebido el derecho de acceso.

Así, en Inglaterra, la misma LT contempla estrictas exigencias que, de verificarse, permiten relativizar la prohibición absoluta de acceso que prevé en ciertas materias y así lo ha entendido la jurisprudencia. En Chile, en cambio, fue la misma CPR la que situó a los derechos como excepción a la transparencia y la LT no pudo alterar tal rígido trazado constitucional, lo que ha contribuido a que el TC haya estimado que no cabe ponderación alguna entre ambos derechos (si la vida privada quedó fuera del derecho de acceso, no hay nada que ponderar) afirmación que ha sido apoyada en ocasiones por los tribunales superiores de

163 De hecho, Lord Hoffman se refiere "al test de necesidad o proporcionalidad" indistintamente, Cámara de los Lores, Campbell v. MGN Ltd [2004] UKHL 22 de 6 de mayo de 2004,2 AC 457, párrafo 59.

164 Además de la doctrina ya citada en términos de la prevalencia general del interés público, cabe señalar que Nogueira Alcalá (2002), p. 191 y (2004), p. 156, fue el primero que sostuvo en nuestro país, y de modo categórico, la accesoriedad de la noción de intimidad disminuida de las "personas de relevancia pública" frente al interés público en la información.

165 Phillipson (2006), pp. 227-228. 
justicia. En España, la LT es de muy reciente aplicación como para entregar algún antecedente al respecto.

En Estados Unidos, la utilización del test que permite discernir entre el interés involucrado en denegar la información frente al interés que supone acceder a ella se encuentra previsto en la misma LT, pues ésta prohíbe la invasión injustificada en el derecho a la privacidad, por lo que asume explícitamente que toda injerencia del derecho de acceso en la esfera de la vida privada debe ser justificada en el entendido que la develación de información debe dar luces sobre el desempeño de los organismos gubernamentales y sus funcionarios.

En segundo término, en los casos en que se ha admitido un ejercicio de balanceo entre el derecho de acceso y la vida privada, esta labor se ha llevado a cabo bajo una premisa comúnmente compartida: que existe un interés público comprometido tanto en el resguardo del derecho de acceso como en la protección del derecho a la vida privada, por lo que ninguna primacía conceptual cabe asignar a un derecho por sobre el otro.

$\mathrm{Al}$ asumirse la concurrencia de un interés público en el resguardo de ambos derechos, lo que inclina la balanza hacia un lado u otro es la determinación de cuál de los derechos concurrentes promueve en mayor medida el interés público. Esto explica que en ocasiones, por ejemplo, el interés público en preservar la seguridad para que las personas denuncien ciertos abusos a la autoridad o sigan participando en determinados concursos públicos puede superar al interés público en que se conozca el nombre de los denunciantes o los motivos por los cuales algunos funcionarios fueron descalificados o sancionados por la autoridad.

En tercer lugar, y aunque el instrumento habitualmente empleado para adjudicar es el test de IP o de proporcionalidad, su aplicación es tan disímil que difícilmente puede hablarse de un mismo test y habitualmente su empleo excluye una de las exigencias más conocidas del mismo en Europa continental: la proporcionalidad en sentido estricto. En todo caso, cualquiera sea la modalidad empleada del test, su denominador común no es otro que contribuir a discernir el interés público predominante entre la disyuntiva de develar la información o retenerla.

En un contexto donde lo relevante es la determinación del interés público, escasa o nula ha sido la incidencia de la idea que afirma la reducción de la vida privada de los funcionarios públicos. Mientras en la Corte Suprema de EE.UU. dicho influjo ha sido inexistente o irrelevante, en Gran Bretaña dicho predicamento ha tenido una incidencia marginal. El TC parece rechazar, en su última jurisprudencia y circunscrito al estricto ámbito de la Ley de Transparencia, la noción de la reducida vida privada de los funcionarios públicos, al considerar que para la CPR todos los funcionarios gozan en igual grado de los mismos derechos, salvo cuando la misma Carta ha restringido expresamente a ciertos 
funcionarios el ejercicio de algunos derechos. En tal contexto, el CPLT es el único organismo que emplea la noción de intimidad reducida del funcionario asociada a una prevalencia anticipada de saber lo que dice relación con la función pública.

En quinto lugar, la prevalencia casuística del derecho de acceso sobre el derecho a la vida privada suele tener lugar toda vez que mediante su ejercicio se informe sobre asuntos de interés público y, además, se entienda que el conocimiento de éstos promueve un bien mayor que el bien que en tal caso supone la reserva de la información. Por tanto, el interés público no viene presuntamente de la mano del mero ejercicio del derecho de acceso, como parece desprenderse muchas veces de la jurisprudencia del CPLT.

Por último, cabe consignar que en materia de acceso a la información, la Corte Suprema norteamericana no ha hecho extensivo al derecho de acceso el trato preferencial otorgado, en cambio, a la libertad de expresión frente a falsedades difamatorias que han afectado a figuras públicas. Esto se explica porque es la misma Ley de acceso la que autoriza la injerencia justificada del derecho de acceso en la vida privada.

\section{Criterios que pueden observarse en la relación antes expuesta entre el derecho a la privacidad del funcionario público y el ejercicio de la libertad de expresión}

Los casos que siguen el estándar sentado de New York Times acuden a una primacía conceptual o jerárquica de la libertad de expresión por sobre el derecho a la honra de los funcionarios públicos, aunque es discutible que dicho estándar pueda hacerse necesariamente extensivo a la vida privada de los funcionarios públicos. El mismo estándar de la real malicia parece no estar concebido para la invasión a la vida privada, como se desprende de su aplicación por la Corte Suprema de EE.UU. y también por otras jurisdicciones que han adoptado dicho criterio.

Fuera del aludido estándar, en ninguno de los casos de derecho comparado exhibidos un derecho precede ni supera in abstracto al otro derecho, por lo que la resolución de la confrontación entre ellos se lleva a cabo acudiendo a distintos modos de ponderación entre los derechos y los bienes que éstos protegen. Cualquiera sea el tipo de ponderación llevada a cabo, la prevalencia de la libertad de expresión sobre la vida privada se produce toda vez que se llegue a la conclusión de que por intermedio de la primera se está informando sobre asuntos de interés público.

En tercer lugar, el influjo de la noción de la privacidad reducida o del mayor riesgo al que se ven expuestas las figuras y funcionarios públicos en su vida privada es mínimo y en ocasiones inexistente. Cuando se emplea, su incidencia es 
accesoria a la existencia de un interés público en la información (Fontevecchia). En otras instancias, ni siquiera es considerado (como en el caso Mitterrand).

Cuando el tipo de ponderación empleado es el test de proporcionalidad -Reino Unido, $\mathrm{CIDH}, \mathrm{TEDH}$ - el denominador común consiste en examinar si la interferencia en el derecho reclamado es proporcional al legítimo fin perseguido y si las razones esgrimidas por la autoridad para intervenir el derecho son relevantes, obviándose las restantes exigencias del test aplicadas por otros tribunales y jurisdicciones, entre ellas, la exigencia de proporcionalidad en estricto sentido.

En quinto lugar, aunque en Chile ninguna de las sentencias acudió al test de proporcionalidad ni tampoco al argumento de la privacidad reducida del funcionario público, en ambos casos se advierte que el interés público es el parámetro escogido para justificar las conductas lesivas a la intimidad, en concordancia con la doctrina. Asimismo, en los fallos es observado el interés público, en mayor o menor grado, como una categoría normativa cuya prevalencia sobre la vida privada se encuentra legitimada en vistas a la consecución de un bien superior -el interés público- por lo que si bien aquella justificación puede venir de la mano del ejercicio de la libertad de expresión, no encuentra su fundamento en el mero ejercicio de ésta, sino que en la obtención de dicho interés común mediante el empleo de aquélla.

Por último, en nuestra escasa jurisprudencia se echa de menos un mayor discernimiento sobre el interés público del artículo 30 de la Ley de Prensa. Si bien es razonable pensar, por ejemplo, que el correcto uso de los beneficios de la seguridad social constituye un aspecto del bien común, no creemos que el asunto sea tan fácilmente descartable sin considerar que también puede existir un interés público -que debe ser ponderable con el anterior- en preservar que los ciudadanos no padezcamos injerencias en nuestra vida privada por medios subrepticios y por vía de engaño (un engaño tan criticable como el llevado a cabo por la querellante y que invocó la sentencia para legitimar el uso de cámaras ocultas).

\section{Observaciones finales a modo de conclusión}

Aparte de lo ya indicado, creemos que los criterios precedentemente expuestos pueden enriquecer la labor jurisprudencial de los tribunales nacionales y el CPLT en sus respectivos discernimientos acerca lo que está en juego, en cada caso, cuando se ven confrontados los ya referidos derechos y bienes.

6.1. La ponderación entre la libertad de expresión y el derecho de acceso a la información, por un lado, y la vida privada de funcionarios públicos, por otro, es un ejercicio bastante más complejo que el resultado de un mero balanceo entre lo público y lo privado, pues habitualmente tanto en el derecho a la vida 
privada como en la libertad de expresión y el derecho de acceso subyace un interés público compartido que es indispensable proteger y promover.

6.2. Al reconocerse la concurrencia de un interés público en resguardar todos los derechos involucrados, la solución difícilmente puede encontrarse en concepciones anticipadas sobre la prioridad de los derechos en juego (jerarquización) ni tampoco en nociones apriorísticas sobre el menor o mayor resguardo de que deben gozar determinadas personas en función de su estatus o función (intimidad reducida de los funcionarios públicos).

6.3. Lo anterior explica que el estatus o calidad de la persona afectada (funcionario público) es a veces un factor inexistente o mínimo y, en otros casos, un criterio accesorio respecto de la concurrencia de un interés público. Si no hay interés público, dicha noción carece de toda relevancia. Si hay interés público, en el mejor de los casos, es un argumento de orden complementario, por lo que este criterio sólo es pertinente en la medida que los hechos privados del funcionario público incidan en el desempeño de su función y esta afectación sea suficientemente relevante (pressing social need) para el bien común como para comenzar a pensar en sobreponerse a la vida privada. Esto se desprende de los fallos de la CIDH, del TEDH y del TCE.

6.4. Incluso en los países que otorgan a la libertad de expresión un valor preponderante frente a los derechos a la honra de las figuras o funcionarios públicos, es discutible que dicha primacía apriorística sea directamente extensible al derecho a la vida privada de los funcionarios públicos.

6.5. En materia de transparencia, la configuración normativa -constitucional y legal- ha evidenciado ser crucial para determinar si procede aplicar algún método ponderativo y en el caso que así sea, bajo qué parámetros procede la resolución de la confrontación entre el derecho de acceso y la vida privada.

6.6. Cualquiera que sea el método empleado en la adjudicación -ponderación o test de proporcionalidad bajo distintas modalidades- la exigencia infaltable es el discernimiento acerca de cuál de los derechos se identifica con el mayor interés público. Así, la prevalencia de la libertad de información no refiere a la primacía conceptual de un derecho sobre otro sino a la del bien común. Por el contrario, nuestros tribunales como el CPLT suelen abordar la contienda de la vida privada con los derechos que usualmente la confrontan, asumiendo cierta preferencia por uno de ellos o en ocasiones descartando cualquier posibilidad de ponderación de los bienes en juego.

6.7. Si el derecho a la vida privada y el derecho de acceso y libertad de expresión no se excluyen conceptualmente, la publicidad de los órganos del Estado o la promoción de la discusión de asuntos públicos, promovida por los dos últimos derechos, no pueden ser considerados como un bien jurídico superior en cuyo beneficio la privacidad deba ceder. La identificación del valor que promueve un derecho con un bien superior respecto de otro derecho impide 
visualizar adecuadamente el interés público real ya que de algún modo éste es asociado con el ejercicio de uno de los derechos en liza.

6.8. ¿Qué justo examen puede darse entre el beneficio que reportaría revelar la información requerida frente al bien que su reserva produciría en el caso concreto cuando se asume anticipadamente que un platillo de la balanza (derecho de acceso o libertad de expresión) pesa más que el otro (vida privada)? ¿Cómo puede servir el TIP para calibrar el peso de los derechos en juego si está inclinado apriorística a favor de sólo uno de ellos?

6.9. El criterio de intimidad reducida del funcionario público o la variada diversidad instrumentos de adjudicación difícilmente corren el riesgo de transformarse en instrumentos de resultado probabilístico o preconcebido si no se advierte que uno y otro están al servicio del interés público, bien éste que debe ser identificado casuísticamente y cuya presencia puede manifestarse tanto en la promoción de la libertad de información y del derecho de acceso, como en el resguardo de la vida privada de los funcionarios públicos. Así, si el ejercicio ponderativo no tiene lugar entre un bien y un mal o entre un bien público y otro privado sino más bien entre dos bienes en juego, el juicio debe focalizarse en discernir cuál de tales bienes configura un bien mayor de acuerdo a las precisas circunstancias del caso.

6.10. Dilucidado lo anterior, lo que resta es reflexionar sobre el tipo de información privada que podría comprometer el ejercicio de la función pública y si dicha afectación tendría la envergadura suficiente como para levantar el velo de la reserva de la aludida información.

\section{BiBLIOGRAFÍA CITADA}

AleinIKOFF, Alexander (1987): "Constitutional Law in the Age of Balancing", en: The Yale Law Journal (volumen XCVI), pp. 943-1008.

BARENDT, Eric (2005): Freedom of Speech, Segunda Edición (New York, Oxford U. Press).

Barendt, Eric (2006): "Privacy and Freedom of Speech", en: A. T. Kenyon y M. Richardson, edit., New dimensions in privacy law: international and comparative perspectives (Cambridge, Cambridge University Press), pp. 11-31.

BAZÁN, Víctor (1998): "El fin y los medios. El standard de la malicia real en la percepción de la Corte: más interrogantes que certezas", en: El Derecho, pp. 1-8.

BAZÁN, Víctor (2008): "El derecho a la vida privada y el derecho a la libertad de información en la doctrina y jurisprudencia de la Corte Suprema de Justicia argentina", en: Estudios Constitucionales (Año 6, № 1), pp. 103-154.

Borgarello, Esther Susana y Juárez Centeno, Carlos (2003): “'Doctrina de la real malicia' y 'Del Balancín-Test'. Su aplicación en materia de información 
periodística por el Superior Tribunal de Justicia de Córdoba", en: Anuario Centro de Investigaciones Jurídicas y Sociales, Universidad Nacional de Córdoba (volumen VI, 2001-2002), pp. 89-103.

BROOKE, Heather (2005): Your Right to Know. How to Use the Freedom of Information Act and Other Access Laws (London, Pluto Press).

Cate, Fred; Fields, Annette y Mcbain, James (1994): "The Right to Privacy and the Public's Right to Know: The "Central Purpose" of the Freedom of Information Act", en: Administrative Law Review (volumen XLVI, No 41), pp. 41-54.

Covarrubias Cuevas, Ignacio (2013): La vida privada de las figuras públicas (Santiago, LegalPublishing).

Covarrubias Cuevas, Ignacio (2014): “ $¿ E m p l e a$ el Tribunal Constitucional chileno el test de proporcionalidad?", aceptado para su publicación en: Estudios Constitucionales (Año $12 \mathrm{~N}^{\circ} 1$ ).

Covarrubias Cuevas, Ignacio (2012): "Las falencias del test de interés público como instrumento de ponderación entre el acceso a la información pública y la vida privada", en: Revista de Derecho de la Pontificia Universidad Católica de Valparaíso ( $\left.N^{\circ} 38\right)$, pp. 499-541.

Dammeier, Dieter (2012): "Fading Privacy Rights of Public Employees", en: Harvard Law \& Policy Review (volumen VI), pp. 297-312.

Díaz Tolosa, Regina Ingrid (2007): "Delitos que Vulneran la Intimidad de las Personas: Análisis crítico del artículo 161-A del Código Penal Chileno", en: lus et Praxis (Año 13, № 1), pp. 291-314.

Eguiguren Prael, Francisco (2004): La libertad de expresión e información y el derecho a la intimidad personal. Su desarrollo actual y sus conflictos (Lima, Palestra Editores).

Flores, Oscar (2006): "Libertad de prensa y derechos personalísimos: criterios de la Corte Suprema de Justicia de la Nación", en: Revista de Derecho Privado y Comunitario (No 2006-2; 'Honor, imagen e intimidad), pp. 305-336.

García Riccl, Diego (2014): "Artículo 16 Constitucional. Derecho a la privacidad", en: Ferrer Mc-Gregor, Caballero y Steiner, Coord., Derechos Humanos en la Constitución. Comentarios de Jurisprudencia Constitucional e Interamericana (México DF, Konrad Adenauer), pp. 1043-1080.

Phillipson, Gavin (2006): "The 'right' of privacy in England and Strasbourg compared", en: A. T. Kenyon y M. Richardson, edit., New dimensions in privacy law: international and comparative perspectives (Cambridge, Cambridge University Press), pp. 184-228.

González Cifuentes, Carolina (2011): "El derecho a la intimidad de los altos cargos", Tesis Doctoral, Universidad de Salamanca. Disponible en: http://gredos. 
usal.es/jspui/bitstream/10366/115568/1/DDPG_Gonzalez_Cifuentes_C._El_ derecho.pdf [visitado el 24/03/14].

Halstuk, Martin (2000): "Blurred Vision: The Supreme Court's FOIA Opinions on Invasion of Privacy", en: Davis, Charles N.-Splichal, Sigman L. (editores), Access Denied. Freedom of Information in the Information Age (lowa, lowa State University Press), pp. 121-153.

Information Commisioner's OfFice (2011): Official Information Held in Private Email Accounts. Disponible en: http://ico.org.uk/for_organisations/guidance_index/ /media/documents/library/Freedom_of_Information/Detailed_specialist_guides/official_information_held_in_private_email_accounts. ashx [visitado el 26/12/2011].

Lasagabaster, Iñaki (2009): Convenio Europeo de Derechos Humanos. Comentario Sistemático, segunda edición, (Navarra, Thomson Reuters).

Lee, Yong (2005): A Reasonable Public Servant (New York, Sharpe).

LóPez Ayllón, Sergio y Posadas, Alejandro (2007): "Las pruebas de daño e interés público en materia de acceso a la información. Una perspectiva comparada", en: Derecho Comparado de la Información (No 9, enero-julio), pp. 21-65. Disponible en: http://www.juridicas.unam.mx/publica/rev/decoin/cont/6/ art/art5.htm [visitado el 15/02/14].

Marshall, William P. y Gilles, Susan (1994): "The Supreme Court, the First Amendment, and Bad Journalism", en: The Supreme Court Review (Volumen MCMXCIV), pp. 169-208.

Meins Olivares, Eduardo (2000): "Derecho a la intimidad y a la honra en Chile", en: lus et Praxis (Año 6, No 1), pp. 303-319.

NASH, Claudio (2008): "Las relaciones entre el derecho de la vida privada y el derecho a la libertad de información en la jurisprudencia de la Corte Interamericana de Derechos Humanos", en: Estudios Constitucionales (Año 6, No 1), pp. 155-169.

Nimmer, Melville (1968): "The Right to Speak from Times to Time: First Amendment Theory Applied to Libel and Misapplied to Privacy", en: California Law Review (volumen LVI Issue 4), pp. 935-967.

Nogueira Alcalá, Humberto (2002): El derecho a la Libertad de Opinión e Información y sus Límites (honra y vida privada) (Santiago, Lexis-Nexis).

Nogueira Alcalá, Humberto (2004): "Pautas para superar las tensiones entre los derechos a la libertad de opinión e información y los derechos a la honra y la vida privada", en: Revista de Derecho, Universidad Austral de Chile (volumen XVII), pp. 139-160.

Nogueira AlcalÁ, Humberto (2011): "El uso del postulado de proporcionalidad en la jurisprudencia de la Corte Interamericana de Derechos Humanos 
sobre libertad de expresión", en: Estudios Constitucionales (Año 9, № 1), pp. 119-156.

Novoa Monreal, Eduardo (1981): "Derecho a la vida privada y libertad de información. Un conflicto de derechos", segunda edición (México D.F, Siglo Veintiuno Editores).

Pizarro, Ramón D. (1997): "La doctrina de la real malicia en la actual jurisprudencia de la Corte Suprema de Justicia. El caso 'Dora Gesualdi' ", en: Jurisprudencia Argentina (III-629).

Sanz Salguero, Francisco Javier (2013): "Solicitud de acceso a la información y tutela de los datos personales de un tercero", en: Revista de Derecho de la Pontificia Universidad Católica de Valparaíso (volumen LX No 2), pp. 457 502.

Serna, Pedro y Toller, Fernando (2000): La Interpretación Constitucional de los Derechos Fundamentales. Una alternativa a los conflictos de Derecho (Buenos Aires, La Ley).

Thomson, John B. (2011): "Los límites cambiantes de la vida pública y la privada", en: Comunicación y Sociedad Universidad de Guadalajara (№ 15, enero-junio), pp. 11-42.

TuRLE, Marcus (2007): "Freedom of information and data protection law -A conflict or reconciliation?", en: Computer Law \& Security Report (volumen XXIII, Issue 6), pp. 514-522.

Vivanco Martínez, Ángela (2006): Curso de Derecho Constitucional. Aspectos dogmáticos de la Carta Fundamental de 1980 (Santiago, Ediciones Universidad Católica de Chile).

\section{NORMAS JURÍDICAS CITADAS}

Constitución de los Estados Unidos, 17 de septiembre de 1787.

Convención Americana sobre Derechos Humanos (Pacto San José de Costa Rica), adoptada el 22 de noviembre de 1969 y ratificada por Chile el 14 de agosto 1990, Decreto No 873, Diario Oficial, 5 de enero de 1991.

España, Anteproyecto de Ley de transparencia y acceso de los ciudadanos a la información pública: Disponible en: http://www.access-info.org/documents/ Access_Docs/Advancing/Spain/Espana_Anteproyecto_Ley_Transparencia. pdf [visitado el 2/04/14].

España, ley № 19/2013, de transparencia, acceso a la información pública y buen gobierno, Boletín Oficial del Estado, 9 de diciembre de 2013.

España, Ley Orgánica № 15/1999, de Protección de Datos de Carácter Personal, Boletín Oficial del Estado, 13 de diciembre de 1999.

Historia de la ley № 20.285, sobre acceso a la información pública, Diario Oficial, 20 de agosto de 2008. 
Ley $\mathrm{N}^{\circ} 19.733$, sobre libertades de opinión e información y ejercicio del periodismo, Diario Oficial, 4 de junio de 2001.

Ley $N^{\circ} 20.050$, sobre reforma constitucional que introduce diversas modificaciones a la Constitución Política de la República, Diario Oficial, 26 de agosto de 2005.

Ley $N^{\circ} 20.285$, sobre acceso a la información pública, Diario Oficial, 20 de agosto de 2008.

Ley $\mathrm{N}^{\circ} 20.414$, reforma constitucional en materia de transparencia, modernización del Estado y calidad de la política, Diario Oficial, 4 de enero de 2010.

Reino Unido, Data Protection Act sobre el tratamiento de datos sobre personas vivas identificables, 22 de agosto de 1998.

Reino Unido, The Freedom of Information Act 2000 chapter 36, que crea un "derecho de acceso" a la información pública, 30 de noviembre de 2000.

\section{JURISPRUDENCIA CITADA}

A. Roberts v. Information Commissioner and Dept. for Business, Innovation and Skills (2009): Tribunal de Información Pública Reino Unido, 20 de noviembre de 2009, EA/2009/0035.

A. Urzúa con PDI (2012): Consejo para la Transparencia, 5 de diciembre de 2012 (Amparo), rol No $\mathrm{C} 1326-12$.

Artículo $5^{\circ}$ inciso $2^{\circ}$ de la ley $N^{\circ} 20.285$ (2013): Tribunal Constitucional, 31 de enero de 2013 (Recurso de Inaplicabilidad), rol No 2246-2012.

Artículo $5^{\circ}$ inciso $2^{\circ}$ y $21 N^{\circ} 1$, letra b) de la ley $N^{\circ} 20.285$ (2012): Tribunal Constitucional, 5 de junio de 2012 (Recurso de Inaplicabilidad), rol № 19902011.

Artículo 2331 del Código Civil (2009): Tribunal Constitucional, 23 de septiembre de 2010 (Recurso de Inaplicabilidad), rol № 1463-2009.

Artículo décimo, letra h) ley No 20.285 (2010): Tribunal Constitucional, 21 de junio de 2011 (Recurso de Inaplicabilidad), rol № 1732-2010.

Barthold v. Germany (1985): Corte Europea de Derechos Humanos, 25 de marzo de 1985, Application No 8734/79.

Bibles v. Oregon Natural Desert Association 519 U.S. 355, 117 S.Ct. 795 (1997): Corte Suprema de los Estados Unidos, 18 de febrero de 1997 (Certiorari).

Bladet Tromsø and Stensaas v. Norway [GC] (1999): Corte Europea de Derechos Humanos, 20 de mayo de 1999, Application No 21980/93.

C. González U. con Municipalidad de Providencia (2010): Consejo para la Transparencia, 27 de enero de 2010 (Amparo), rol No C402-09.

Campbell v. MGN Ltd (2004): 2 AC 457, Cámara de los Lores, 6 de mayo de 2004. 
Claude Reyes y otros (2006): Corte Interamericana de Derechos Humanos, Serie C No 151, 19 de septiembre de 2006.

Comisionado de Información Pública de Reino Unido, Decisión FS50063659, 12 julio de 2005.

Comisionado de Información Pública de Reino Unido, Decisión FS50062124, 25 de agosto de 2005.

Comisionado de Información Pública de Reino Unido, Decisión FS50068973, 24 de noviembre de 2005.

Common Services Agency v. Scottish Information Commissioner [2008] UKHL 47, Cámara de los Lores, 9 de julio de 2008.

Consejo Nacional de la Cultura y las Artes con Consejo para la Transparencia (2013): Corte de Apelaciones de Valparaíso, 19 de abril de 2013 (Recurso de Reclamación), rol № 1560-2012.

Corporate Officer of the House of Commons v. The Information Commissioner \& Ors [2008] EWHC 1084 (Admin), Corte Real de Justicia de Londres, 16 de mayo 2008.

Correos electrónicos, Artículo $5^{\circ}$ inciso $2^{\circ}$ de la ley $N^{\circ} 20.285$ (2012): Tribunal Constitucional, 11 de septiembre de 2012 (Recurso de Inaplicabilidad), rol $N^{\circ} 2153-2011$.

Creekside Forum v. Information Commissioner and Dept. for Culture, Media and Sport (2009): Tribunal de Información Pública Reino Unido, 28 de mayo de 2009, EA/2008/0065.

Curtis Publishing Co. v. Butts, 388 U.S. 130, 164 (1967): Corte Suprema de los Estados Unidos, 12 de junio de 1967 (Certiorari).

D. Cea B. con Municipalidad de Limache (2010): Consejo para la Transparencia, 8 de enero de 2010 (Amparo), rol No A307-09.

D. Mancilla G. con Municipalidad de Talagante (2010): Consejo para la Transparencia, 29 de junio de 2010 (Amparo), rol № C95-10.

Dept. of Justice v. Reporters Committee for Freedom of the Press 489 U.S. 775 (1989): Corte Suprema de los Estados Unidos, 22 de marzo de 1989 (Certiorari).

Dichand and others v. Austria (2002): Corte Europea de Derechos Humanos, 26 de febrero de 2002, Application No 29271/95.

Dirección Nacional del Servicio Civil con CPLT (2012): Corte de Apelaciones de Santiago, 26 de julio de 2012 (Recurso de Ilegalidad), rol No 7514-2010.

Editions Plon v. France (2004): Corte Europea de Derechos Humanos, 18 de agosto de 2004, Application No 581485/00.

F. Herreros L. con Municipalidad de Recoleta (2010): Consejo para la Transparencia, 20 de agosto de 2010 (Amparo), rol № C335-10. 
Fisco de Chile / Rodríguez Sebastián - Aguirre Jaime - Guillier Alejando - Caldichoury Juan - Reyes Fernando - Poblete Rodolfo (2005): Tercer Juzgado del Crimen de Santiago, 15 de julio de 2005, rol No 209.909-2003.

Fisco de Chile / Rodríguez Sebastián - Aguirre Jaime - Guillier Alejando Caldichoury Juan - Reyes Fernando - Poblete Rodolfo (2006): Corte de Apelaciones de Santiago, 9 de mayo de 2006 (Recurso de Apelación), rol No 21722-2005.

Fontevecchia v. Argentina (2011): Corte Interamericana de Derechos Humanos, Serie C No 193, 27 de enero de 2009.

Garrison v. Lousiana 379 U.S. 74, 77 (1964): Corte Suprema de los Estados Unidos, 23 de noviembre de 1964 (Certiorari).

Gertz v. Robert Welch 418 U.S. 323, 344, 363 (1974): Corte Suprema de los Estados Unidos, 25 de junio de 1974 (Certiorari).

H. Osses S. con Servicio Nacional de Aduanas (2011): Consejo para la Transparencia, 18 de enero de 2011 (Amparo), rol No C626-10.

Handysi Campbell v. MGN Ltd [2004] de v. the UK (1976): Corte Europea de Derechos Humanos, 7 de diciembre de 1976, Application No 5493/71.

Herrera Ulloa vs. Costa Rica (2004): Corte Interamericana de Derechos Humanos, Serie C No 107, 2 de julio de 2004.

J. Gómez G. con Mineduc (2011): Consejo para la Transparencia, 7 de enero de 2011 (Amparo), rol No C816-10.

J. P. de la Carrera con Carabineros de Chile (2009): Consejo para la Transparencia, 28 de julio de 2009 (Amparo), rol No A45-09.

Jaime Lara y otros con María Luisa Cordero (2011): Vigésimo segundo Juzgado del Crimen de Santiago, 30 de abril de 2011, rol № 3913-2003.

Jaime Lara y otros con María Luisa Cordero (2012): Corte de Apelaciones de Santiago, 1 de agosto de 2012 (Recurso de Apelación), rol № 1781-2011.

Jaime Lara y otros con María Luisa Cordero (2013): Corte Suprema, 21 de agosto de 2013 (Recurso de Casación en el fondo), rol № 8393-12.

Kimel vs. Argentina (2008): Corte Interamericana de Derechos Humanos, Serie C N 177,2 de mayo de 2008.

L. Silva Á. con Dirección del Trabajo (2009): Consejo para la Transparencia, 31 de julio de 2009 (Amparo), rol № A53-09.

La Colegiación Obligatoria de Periodistas (1985): Corte Interamericana de Derechos Humanos, Opinión Consultiva OC-5/85, Serie A No 5, 13 de noviembre de 1985.

La expresión "leyes" en el artículo 30 de la Convención Americana sobre Derechos Humanos (1986): Corte Interamericana de Derechos Humanos, Opinión Consultiva OC-6/86, Serie A Nº 6, 9 de mayo de 1986. 
Lancashire County Council v. Information Commissioner (2007): Tribunal de Información Pública Reino Unido, 30 de julio de 2007, EA/2006/0027.

Lindon, Otchakovsky-Laurens y July v. France [GC] (2007): Corte Europea de Derechos Humanos, 22 de octubre de 2007, Application No 21279/02 y 36448/02.

Lingens vs. Austria (1986): Corte Europea de Derechos Humanos, 8 de julio de 1986, Application No 9815/82.

López Álvarez vs. Honduras (2006): Corte Interamericana de Derechos Humanos, Serie C No 141, 1 de febrero de 2006.

Luz María Virginia de Lourdes Donoso Arteaga con Revista Caras (1998): Corte de Apelaciones de Santiago, 10 de agosto de 1998.

M. A. Correa P. con SVS (2012): Consejo para la Transparencia, 23 de noviembre de 2012 (Amparo), rol No C836-12.

Ministerio de Transportes y Telecomunicaciones con CPLT (2013): Corte de Apelaciones de Santiago, 12 de junio de 2013 (Recurso de llegalidad), rol No 5077-2012.

Mr. Colin P. England (1) and London Borough of Bexley (2) v. Information Commissioner (2007): Tribunal de Información Pública Reino Unido, 10 de mayo de 2007, EA/2006/0060 \& 0066.

National Archives and Records Admin. v. Favish 541 U.S 157 (2004): Corte Suprema de los Estados Unidos, 30 de marzo de 2004 (Certiorari).

New York Times v. Sullivan 376 U.S. 254, 276 (1964): Corte Suprema de los Estados Unidos, 9 de marzo de 1964 (Certiorari).

O'Connor v. Ortega 480 U.S. 709, 715, 732-33 (1987): Corte Suprema de los Estados Unidos, 31 de marzo de 1987 (Certiorari).

P. H. Pacheco con Municipalidad de Providencia (2009): Consejo para la Transparencia, 22 de septiembre de 2009 (Amparo), rol № A 115-09.

P. H. Pacheco con Municipalidad de Las Condes (2009): Consejo para la Transparencia, 2 de octubre de 2009 (Amparo), rol No A159-09.

Palamara vs. Chile (2005): Corte Interamericana de Derechos Humanos, Serie C No 135, 22 de noviembre de 2005.

Pedersen and Baadsgaard v. Denmark [GC] (2004): Corte Europea de Derechos Humanos, 17 de diciembre de 2004, Application No 49017/99.

Ponzetti de Balbín con Editorial Atlántida S.A. (1984): Corte Suprema de la Nación Argentina, 11 de diciembre de 1984, Fallos 306:1892.

Promovido por don Joaquín Estefanía Moreira y otros frente a las Sentencias de la Sala de lo Civil del Tribunal Supremo y de la Audiencia Provincial de Madrid (1999): Tribunal Constitucional de España, 25 de octubre de 1999 (Recurso de Amparo), Sentencia 192/1999. 
Promovido por don Manuel Rincón Granados frente a las Sentencias de la Sala de lo Penal del Tribunal Supremo y de la Audiencia Provincial de Málaga (2001): Tribunal Constitucional de España, 27 de junio de 2001 (Recurso de Amparo), Sentencia 148/2001.

Promovido por Sílex Media Limitada y Compañía, sociedad en comandita, frente a la Sentencia de la Sala Primera del Tribunal Supremo (2004): Tribunal Constitucional de España, 15 de abril de 2004 (Recurso de Amparo), Sentencia 54/2004.

R. Novakovic C. con ISP (2012): Consejo para la Transparencia, 5 de septiembre de 2012 (Amparo), rol No C707-12.

R. Novakovic C. con SII (2011): Consejo para la Transparencia, 7 de diciembre de 2011 (Amparo), rol No C1033-11.

R. Novakovic C. con Subsecretaría de Salud Pública (2010): Consejo para la Transparencia, 6 de agosto de 2010 (Amparo), rol No C198-10.

R. Rincón G. con Intendencia Región del Libertador Bernardo O'Higgins, Seremi de Bienes Nacionales Región del Libertador Bernardo O'Higgins (2011): Consejo para la Transparencia, 24 de agosto de 2011 (Amparo), rol $\mathrm{N}^{\circ} \mathrm{C} 713-11$.

R. Sotomayor V. con Municipalidad de Vitacura (2009): Consejo para la Transparencia, 15 de julio de 2009 (Amparo), rol No A47-09.

Recurso de Queja SII (2014): Corte Suprema, 15 de enero de 2014 (Recurso de Queja), rol No 7484-2013.

Requerimiento de Diputados respecto del artículo $1^{\circ}$, inciso tercero; artículo $9^{\circ}$, inciso primero; artículo 20, inciso segundo, y artículo 43, inciso segundo, del proyecto de ley sobre "Libertad de expresión, información y ejercicio del periodismo" (1995): Tribunal Constitucional, 30 de octubre de 1995 (Recurso de Inconstitucionalidad), rol № 226-1995.

Ricardo Canese vs. Paraguay (2004): Corte Interamericana de Derechos Humanos, Serie C No 111, 31 de agosto de 2004.

Robin Makin v. Information Commissioner and M. of Justice (2009): Tribunal de Información Pública Reino Unido, 1 de junio de 2009, EA/2008/0048.

Rosenblatt v. Baer, 383 U.S. 75, 76 (1966): Corte Suprema de los Estados Unidos, 21 de febrero de 1966 (Certiorari).

Rosenbloom v. Metromedia, Inc. 403 U.S. 29, 34 (1971): Corte Suprema de los Estados Unidos, 7 de junio de 1971 (Certiorari).

Secretaría General de la Presidencia con CPLT (2013): Corte de Apelaciones de Santiago, 23 de julio de 2013 (Recurso de Reclamación), rol No 2496-2012. Secretaría General de la Presidencia con CPLT (2013): Corte Suprema, 29 de agosto de 2013 (Recurso de Queja), rol No 5040-2013. 
The Sunday Times v. United Kingdom (1979): Corte Europea de Derechos Humanos, 26 de abril de 1979, Application $N^{\circ}$ 6538/74.

U.S. Dept. of Air Force v. Rose 425 U.S. 352, 372 (1976): Corte Suprema de los Estados Unidos, 1 de abril de 1976 (Certiorari).

U.S. Dept. of Defense v. Federal Labor Authority 510 U.S. 487 (1994): Corte Suprema de los Estados Unidos, 23 de febrero de 1994 (Certiorari).

U.S. Dept. of State v. Ray 502 U.S. 164 (1991): Corte Suprema de los Estados Unidos, 16 de diciembre de 1991 (Certiorari).

Von Hannover v. Germany (2005): Corte Europea de Derechos Humanos, 24 de junio de 2004, Application № 59320/00.

Von Hannover v. Germany No 2 (2012): Corte Europea de Derechos Humanos, 7 de julio de 2012, Application No 40660/08. 